\title{
Approaches for adding value to anaerobically digested dairy fiber
}

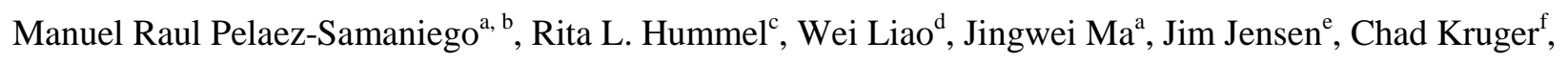 \\ Craig Frear ${ }^{\mathrm{g}}$, \\ ${ }^{a}$ Department of Biological Systems Engineering, Washington State University, Pullman, WA. \\ ${ }^{\mathrm{b}}$ Faculty of Chemical Sciences, Universidad de Cuenca, Cuenca, Ecuador. \\ ${ }^{\mathrm{c}}$ Department of Horticulture, Washington State University, Pullman, WA. \\ ${ }^{\mathrm{d}}$ Department of Biosystems and Agricultural Engineering, Michigan State University, East Lansing, MI \\ ${ }^{\mathrm{e}}$ Energy Program, Washington State University, Olympia WA. \\ ${ }^{\mathrm{f}}$ Center for Sustaining Agriculture and Natural Resources, Washington State University, Wenatchee, WA \\ ${ }^{\mathrm{g}}$ Regenis, Ferndale, WA
}

\begin{abstract}
One of the consequences of the increase of large dairy concentrated feeding operations (CAFOs) is the abundance of dairy manure that needs to be disposed of or used in some way. CAFOs can become bio-refineries, harnessing the manure for heat, power, fuel, chemicals, fertilizers, fiber, wood composites, and biochar for production of multiple value-added co-products. The objective of this paper is to review options for using dairy manure fiber and its corresponding anaerobically digested (AD) fiber. Bedding for cows remains a common choice for employing the separated $\mathrm{AD}$ fiber. However, research has shown that $\mathrm{AD}$ fiber has potential for using it as a component of growth substrates used in container plant production systems, for producing composite materials, or as a feedstock for both chemical and thermochemical operations. Potential uses of AD fiber such as composite materials and liquid fuels are proposed based on experiences employing the manure and its fiber (both without a previous AD step and after AD). Thermochemical processing (e.g., liquefaction and pyrolysis) of AD fiber for fuels and chemicals has been conducted at laboratory level and still needs further study at larger scale. Gasification of AD fiber is a promising option since there is potential for integration of current methane production with methane produced from thermal gasification.
\end{abstract}

Keywords: Dairy manure; Anaerobic digestion; Dairy fiber; Value-Adding operations; Thermochemical processing; Bio-Refinery.

(C) 2017. This manuscript version is made available under the Elsevier user license http://www.elsevier.com/open-access/userlicense/1.0/ 


\section{Introduction}

Dairy farmers in several places worldwide are facing the difficulty of managing large amounts of dairy manure on concentrated animal feeding operations (CAFOs). In the United States (US), the midpoint size of dairies has risen from 275 to 900 cows, resulting in roughly 1800 large CAFO dairies with a wet-cow equivalent (WCE) herd size of 1000 or greater (many on the order of 5000,10000 or even 20000). These large CAFOs produce over $50 \%$ of the milk supply [1]. With a production rate of 64-69 $\mathrm{kg}$ wet manure per cow per day (14-18\% dry weight), these CAFOs, can produce a remarkable amount of manure and manure wastewater.

At such large scales, these dairy CAFOs are capable of becoming bio-refineries, harnessing the manure for heat, power, fuel, chemicals, fertilizers, fiber, wood composites, and chars/carbons, while mitigating climate, air, water and human health concerns associated with the manure [2, 3]. A baseline for many CAFO bio-refinery visions is an anaerobic digestion $(\mathrm{AD})$ operation for production of biogas and its resulting revenues from either combined heat and power (CHP) or renewable, compressed natural gas fuel (CNG), while also yielding significant environmental benefits related to methane capture and conversion, pathogen and odor destruction, and organic matter stabilization $[4,5]$. Unfortunately, adoption of even a baseline AD model on CAFOs within the US is currently limited to around 244 farms [6]. While several hurdles exist, a key limit to adoption rests on business economics with revenue from the most traditional biogas off-take, electrical power, simply not enough to supply a preferred return on investment $[7,8]$. However, incorporation of additional co-products and their revenues can have profound impacts towards financial viability. These additional revenue items can include tipping fees (as well as additional biogas/power) from off-farm organics, carbon credits, and of importance to this review paper, sales from the digested fibrous solid and/or its value-added products.

A key component within dairy manure is recalcitrant fibrous solids (fiber) surviving the cow's digestion process, which comprises roughly $40-50 \%$ of total solids (TS) in the as-produced manure $[9,10]$. This fiber remains for the most part intact and undigested after incorporation in typical mesophilic AD units, representing, in its mechanically separated form, approximately $40 \%$ of the AD effluent TS [11]. This fiber can be an important raw source for value-added processing and product development. Table 1 presents a summary of some characteristics of AD dairy fiber according to two works. The values suggest that $\mathrm{AD}$ characteristics depend on the origin of the material. Although hemicellulose degradation is expected during the AD process, it is seen that an important portion of it 
remains intact. Nitrogen content in AD dairy fiber is high when compared with other lignocellulosic materials such as wood.

Table 1. Some characteristics of AD dairy fiber (dry basis)

\begin{tabular}{|c|c|c|c|}
\hline \multirow[t]{2}{*}{ Parameter } & \multirow[t]{2}{*}{ Unit } & \multicolumn{2}{|l|}{ Value } \\
\hline & & $\operatorname{Ref}[10]$ & $\operatorname{Ref}[12]$ \\
\hline TS (total solids) & $\%$ & 24.43 & - \\
\hline VS (volatile solids) & $\% \mathrm{TS}$ & 92.00 & - \\
\hline Density & $\mathrm{kg} / \mathrm{m}^{3}$ & 400.56 & - \\
\hline $\mathrm{C}$ & $\%$ & - & $39.1 \pm 0.4$ \\
\hline $\mathrm{N}$ & $\%$ & 1.42 & $3.3 \pm 0.2$ \\
\hline $\mathrm{P}$ & $\%$ & 0.28 & $1.1 \pm 0.0$ \\
\hline K & $\%$ & 0.68 & $1.4 \pm 0.0$ \\
\hline $\mathrm{Ca}$ & $\%$ & 1.44 & $4.8 \pm 0.6$ \\
\hline $\mathrm{Mg}$ & $\%$ & 0.28 & $0.8 \pm 0.1$ \\
\hline $\mathrm{Na}$ & $\%$ & 0.27 & - \\
\hline S & $\%$ & 0.50 & $1.0 \pm 0.0$ \\
\hline $\mathrm{Cu} ; \mathrm{Zn} ; \mathrm{Mn} ; \mathrm{Fe} ; \mathrm{B}$ & ppm & $99.33 ; 98.67 ; 929.33 ; 27.83$ & - \\
\hline $\mathrm{C} / \mathrm{N}^{\mathrm{a}}$ & - & 36.70 & - \\
\hline Ash & $\%$ & - & $13.7 \pm 0.1$ \\
\hline Extractives & $\%$ & - & $11.7 \pm 0.1$ \\
\hline Cellulose (Glucose) & & $35.7 \pm 1.4$ & $23.6 \pm 0.3$ \\
\hline $\begin{array}{l}\text { Hemicelluloses (Galactose, Arabinose, } \\
\text { Xylose, Mannose) }\end{array}$ & $\%$ & $9.2 \pm 1.0$ & $17.5 \pm 0.5$ \\
\hline Acid soluble lignin & $\%$ & - & $1.8 \pm 0.0$ \\
\hline Acid insoluble lignin & $\%$ & $27.7 \pm 0.7$ & $27.6 \pm 0.1$ \\
\hline
\end{tabular}

Pretreatment through various biological, chemical, mechanical, and thermal methods $[13,14,15]$, and subsequent incorporation of the fiber for a second run at the $\mathrm{AD}$ process could allow for greater access to its biogas potential. For example, Biswas et al., [16] reported that a wet explosion process, calculated in conjunction with known US AD and fiber operational data, could increase $\mathrm{AD}$ methane production by up to $41 \%$. While an impressive increase in gas productivity as well as potential electrical or CNG sales, net revenues resulting from the pretreatment costs and extra biogas should be compared to other value-added uses for the digested fiber. Recognizing this pretreatment pathway as a viable route (especially if value of the produced biogas and final energy/fuel product increases) is of 
merit but in addition, continuing down the alternate path of obtaining value to the existing AD fiber appears as a promising pathway for complete use of the fiber and for providing dairy farmers with strategies to increase revenues.

Although recent works $[17,18]$ review some options for adding value to $\mathrm{AD}$ agricultural and food waste, there is a lack of works focusing on AD dairy fiber. The objective of this paper is to summarize the literature regarding numerous existing and potential value-added uses for AD dairy fiber. Some discussions rely on processing and use of the non-digested fiber fraction or the whole dairy manure. It is expected that the review will provide information to those interested in planning strategies for adding value to $\mathrm{AD}$ dairy fiber.

\section{AD fiber for bedding/soil amendment/peat replacement}

\subsection{Manure and/or AD fiber as feedstock for dairy bedding and soil amendments}

Bedding for cows remains a common first choice for using the separated AD fiber [19, 20]. From a mass balance perspective, a WCE produces approximately 7-9 $\mathrm{m}^{3} /$ year of wet digested fiber (70-75\% moisture content-MC) from the back end of the digester and liquid/solids separation [11]). Simple mechanical screens with scale variable capital (\$45-80 per cow) and operating ( $\$ 8-16$ per cow per year) costs can effectively separate the fiber from the manure and/or wastewater [21]. The digestion process both reduces pathogens (2-3 log reduction) [11] and stabilizes the organic carbon in the effluent fiber, yielding a product that currently represents approximately $300000 \mathrm{WCE}$ in the US [22]. Typical revenues calculated from offset savings of not purchasing and using sawdust, straw, or other materials for bedding are on the order of $\$ 6-8$ per wet $\mathrm{m}^{3}$ (\$21-27 per wet $\mathrm{t}$ ), although in some states and regions with high feedstock costs this range could be higher [23]. Farm mass balances show an approximate internal need for $50 \%$ of the produced fiber while the remaining $50 \%$ could be used for other value-added processing or sold as bedding to nearby dairies without a digester [11]. Several companies have entered the marketplace with additional treatment and drying technologies that further prepare the digested or even non-digested fiber for use as animal bedding. These, among others, include Eco-Composites (Holland, MI), who through a patented drying and treatment process, produces a Perfect Cycle ${ }^{\circledR}$ Natural Bedding that is sold in pelletized form to regional dairies, rabbit breeders and horse stables [24, 25] and Nutrient Control Systems (Chambersburg, PA) who selectively target longer fiber particles from non-digested, separated fibrous solids and treats them in short-cycle in-vessel composters. 
After separation, another common method to add value to AD fiber is to apply basic compost processing methodsadding aeration and space under controlled conditions for sufficient time to compost the fiber [20]. As part of the $\mathrm{AD}$ process, carbon is partially converted into methane, thus $\mathrm{AD}$ fiber can have carbon to nitrogen ratios lower than raw manure, but still within the range and with the necessary moisture content for successful composting, especially if the fiber is co-composted with other materials to obtain even more advantageous carbon to nitrogen ratios and other compost properties [26]. While AD fiber may already have reduced pathogen content, hot composting practices can give additional assurance of pathogen reduction and prevent regrowth of pathogens during storage [26]. Composting stabilizes the carbon and other nutrients in the fiber material, darkening the fiber, making it look more like soil. It also reduces the volume and can drive off some of the moisture, producing a product that is easier to handle and with less weight. After composting, the darker composted fiber can be marketed for higher value, either alone or as a desirable ingredient in blended nursery and garden soil mixes [10, 26, 27]. Typical price points for bulk sales of composted dairy manure/fiber containing appreciable concentrations of nitrogen $(\sim 15 \mathrm{~kg} \mathrm{~N} / \mathrm{t})$ are around $\$ 20 / t$ with an additional $\$ 10 / t$ charge for large-scale field application [28].

A more specialized form of composting with practical application using composted whole dairy manure and/or dairy fiber is vermicomposting [29, 30]. Vermicompost is a process in which specialized worms are grown in the presence of organic residuals using a variety of continuous production systems, such as low-cost floor beds, containers or boxes, and raised gantry-fed beds, for production of a greater population of earthworms (e.g., animal or fish protein) or for production of earthworm castings or vermicompost [30]). Research has established the favorable conditions for using earthworms to process cattle or dairy manure solids, as well as bio-solids resulting from AD of wastewater [30]. The earthworms fragment and consume the fibrous organic matter obtaining nutrition from the microorganisms that grow on the feedstock [29].

\subsection{AD Fiber as a component of growth substrates used in container plant production systems}

Greenhouse and nursery production of high-value crop plants is a specialized segment of the horticulture industry. Both woody and herbaceous plants are grown in tightly controlled environments [31] and nearly $80 \%$ of the plants are grown in containers [32]. The growth substrates used in container production are typically soilless and at least 70 to $80 \%$ of the ingredients are organic materials [32]. The standard organic components of container substrates have been peat and bark from various softwood and hardwood tree species [33, 34, 35, 36,37]. Both substrates, however, 
are experiencing sustainability and/or price pressures, with sphagnum peat experiencing environmental concerns, production and transportation costs price hikes, as well as reduced availability [37, 38, 39]. Bark is also becoming scarce due to demand from other uses, reduced timber harvests, and rising prices [40, 41]. The demand for sustainable alternatives to peat and bark has prompted research to develop alternative substrates $[35,37,42,43,44$, $45,46,47,48]$.

Properly treated, typically by composting or $\mathrm{AD}$, organic wastes have the potential to substitute for peat and bark as components of the growth substrates in containerized plant production systems $[37,46,47,48]$. Specific to AD fiber, there is a small but growing body of research showing that $\mathrm{AD}$ fiber has the potential to meet the requirements for a component of high-quality growth substrates $[49,50,51,52,53,54,55]$. To produce container crops according to schedule, greenhouse and nursery growers must have reliable source of high quality growth substrates that are consistent over time and that have appropriate physical and chemical properties for their crops [34, 46, 56, 57]. Key physical properties of the substrate include: total porosity, water-holding capacity, air-filled porosity, $\mathrm{pH}$, soluble salts content, and cation exchange capacity. Most organic substrates have 75 to $85 \%$ pore space [34]. Although requirements may vary by crop, a generally accepted range for water holding capacity is 20 to $60 \%$ while 10 to 20 $\%$ air-filled porosity is typically considered desirable [33]. The $\mathrm{pH}$ range for plants grown in organic soils and soilless substrates is about 1.0 to 1.5 units lower than for mineral soils [33], with the recommended $\mathrm{pH}$ range for most container substrates being 5.5 to $6.5[58,59]$. Additionally, substrates for growing plants in containers must be standardized, reproducible, available, and economical. The substrates must be free from diseases, pests, harmful chemicals, heavy metals and dangerous foreign materials, easy to work with, and have no objectionable odor.

Early research to determine the potential for the fibrous material from AD dairy manure to act as a peat substitute in soilless growth substrates has been conducted in Israel [49, 60]. Chen et al. [60]) sieved and leached the digested slurry to produce a fibrous material resembling peat that was given the commercial name cabutz. Tests of its physical and chemical properties indicated cabutz was a well-aerated growth substrate with high water and nutrient holding capacities, albeit with slightly basic $\mathrm{pH}$ (7.0 to 7.6) and very high electrical conductivity (EC, a measure of soluble salts), necessitating leaching before use as a growth substrate [60]. In a series of experiments, Raviv et al. [49] tested cabutz as a peat substitute for plant growth substrates, for a seed germination medium and for rooting media. As a growth substrate cabutz produced marketable size Philodendron wendlandii plants a month earlier and 
$34 \%$ larger than plants grown in peat (3 versus 4 months). For other plants there were no growth differences between the cabutz and peat substrates.

In 28 greenhouse experiments with petunia plants conducted over several years, MacConnell and Collins [50] used $\mathrm{AD}$ fiber as a one-to-one replacement for peat moss in container substrates. The authors found dairy fiber to have physical properties (aeration porosity and water holding capacity) similar to peat but the average $\mathrm{pH}$ of 8.4 and EC of $3.5 \mathrm{dS} / \mathrm{m}$ were much higher than peat moss. The authors found that amending AD fiber with elemental sulfur to lower the $\mathrm{pH}$ produced petunia shoot growth and leaf greenness equal to peat when used as a one to one replacement (70 \% by volume) but that the addition of gypsum along with the sulfur was needed to produce both shoot and root systems equal to peat.

Krucker et al. [51] compared several locally available peat substitutes, including AD fiber, for greenhouse production of chrysanthemum 'Shasta' at two nitrogen fertilizer rates using conventional overhead irrigation and a capillary mat sub-irrigation system. A commercially formulated, bagged peat-perlite substrate consisting of 70 to 80 $\%$ sphagnum peat moss was the control. AD fiber was used alone or mixed 1 to $1(50 \%)$ by volume with Douglasfir bark. Analysis of chemical and physical properties showed the EC of the dairy fiber was very high, $8.3 \mathrm{dS} / \mathrm{m}$, and even when mixed 1 to 1 with bark the EC was $5.4 \mathrm{dS} / \mathrm{m}$, above the recommended range for container substrates. Leaching the $\mathrm{AD}$ fiber with a volume of water equal to four times the volume of the substrate lowered the fiber EC to $3.6 \mathrm{dS} / \mathrm{m}$ and the fiber to bark mix to $2.3 \mathrm{dS} / \mathrm{m}$. After leaching, the $\mathrm{AD}$ fiber and fiber to bark substrates had $\mathrm{pH}$ values of 7.8 and 6.7 , respectively. Nine weeks after transplant 'Shasta' chrysanthemums were ready to market and data was collected on root and shoot growth, plant visual quality, and number of flower buds [51]. Results of statistical comparisons for low and high $\mathrm{N}$ fertilized chrysanthemums in both the overhead and sub-irrigation treatments indicated there were only two significant differences for any of these measurements between the peat perlite control and either of the AD fiber substrates. The two significant differences indicated visual quality of the overhead and sub-irrigated $\mathrm{AD}$ fiber grown plants fertilized at the low $\mathrm{N}$ rate was higher than the plants growing in peat-perlite control. Root growth of plants in the experimental substrates was similar to the controls in both irrigation systems. In two recent works, Lamont and Elliot $[54,55]$ evaluated the effect of potting media containing bark-peat-perlite and bark-AD dairy fiber-perlite on the growth of several types of ornamental plants and the nutrients availability in the potting soil. Plants tested were "Jack Frost" brunnera (Brunnera macrophylla I.M. 
Johnst), "Moonbeam" coreopsis (Coreopsis verticillata L.), "Whoopsa-Daisy" Shasta daisy (Leucanthemum $\times$ superbum Bergmans ex J.W. Ingram), “Kobold Original” liatris (Liatris spicata (L.) Willd.), "David” phlox (Phlox paniculata L.), and Poinsettias (Euphorbia pulcherrima). Results showed that AD fiber can be effective for substituting part (e.g., up to $50 \%$ ) of peat in potting media for a diversity of ornamental plants.

Hummel et al. [53] compared growth and quality of containerized 'Little Hero Flame' marigold and 'Golden California Wonder' pepper plants in an experimental substrate made of dairy manure-food waste AD solids mixed 1 to 1 by volume with Douglas-fir bark to the same commercially available peat:perlite substrate as used by [51]. At the time of harvest, all plants were considered marketable but results were not consistent across species [53]. Marigolds in the digester soilds:bark substrate fertilized with 200 ppm N every-other-day were not significantly different in shoot growth index, dry weight or visual quality but did have more flower buds than marigolds in the peat-perlite control substrate. The peppers had similar shoot growth index and flower bud numbers, but their dry weight and visual quality were lower in the digester solids:bark substrate. When the nitrogen rate was lower (i.e., 200 ppm N every-fourth-day), marigolds in the digester solids:bark and peat-perlite substrates were similar in all measured parameters except that visual quality of plants in peat-perlite was slightly higher. At the low $\mathrm{N}$ rate, analysis of pepper measurements indicated plants in the peat-perlite control were larger of higher quality and had 15 rather than 10 flower buds. Although all plants in this experiment were marketable, the results indicate the need to test experimental substrates on a wide range of plant species under different growing conditions.

Crippa et al. [52] tested the solid fraction of $\mathrm{AD}$ effluent from digestion of cow manure and pig slurry for its potential as a container substrate. The AD solid was used alone and in combination with sphagnum peat at 25 and 50 $\%$ by volume to germinate cress and barley seeds and to grow lettuce plants. The authors found that reducing the salinity and lowering the $\mathrm{pH}$ of the AD solids was necessary and did so by mixing it with peat. Their results indicated the AD solids could be a valuable component in plant growth substrates replacing up to half of the peat amount.

Although not anaerobically digested, screened solids from a 1600-cow Florida dairy were processed through a horizontal drum digester or composter to produce a dairy manure peat-substitute marketed as cowpeat [61]). In experiments with foliage plants, Li et al. [62]) replaced peat with cowpeat at $10 \%$ increments from 10 to $60 \%$ in 
the propagation substrate for germinating Asparagus densiflorus seeds and for rooting cuttings of Epipremnum aureum, Philodendron scandens ssp. oxycardium and Ficus benjamina 'Florida Spire'. Results indicated that all cuttings rooted and seed germination rates of cowpeat-substituted substrates were greater than or similar to the peat substrates. Li et al. [62] concluded that there was potential to use cowpeat in foliage plant propagation and for foliage plant production. Shober et al. $[63,64])$ used cowpeat obtained from the same source at about the same time as [62] as a peat substitute in substrates for the container production of three annual bedding plants and three woody landscape shrubs. Their results indicated substrates formulated with cowpeat appeared to be commercially acceptable for production of container-grown bedding plant and woody landscape shrub species based on growth and quality [63]. Cowpeat is a commercially available peat substitute [65].

Determining the volume and constituents of soilless growth substrates used in container plant production is difficult [47]. The most reliable data comes from the European Union (EU) where the volume of growth substrate constituents produced in 13 EU countries was determined in a survey by [39]) for the year 2005. Results indicated a total production of 34.6 million $\mathrm{m}^{3}$ with $77.4 \%$ of the total being peat, $5.1 \%$ other organics and $9.1 \%$ composted materials. Germany was the largest producer of growth substrates surveyed with a reported total of $9.1 \mathrm{million}^{3}$, $93 \%$ of which was peat. Italy was the second largest producer with 5.27 million $\mathrm{m}^{3}$ total constituents comprising 74 $\%$ peat. The use of composted biodegradable waste was increasing in many of the countries surveyed and was significant in Italy, amounting to $5 \%$ of the total constituents. Unfortunately, the volume of substrate constituents used in North America is difficult to estimate [47]. Recent data are not available but Carlile et al. [47] reported in 2002 to 2003 the Canadian Peat Moss Association estimated its members supplied approximately $8.7 \mathrm{million}^{3}$ of peat to the United States. Canada is the source of most of the peat used in the U.S.

According to Carlile et al. [47] growth substrates used by the greenhouse and nursery industry fall into three general categories: 1) substrates for propagation either by seeds or cuttings and production in small containers; these substrates are typically 50 to $70 \%$ peat by volume with an inorganic component like vermiculite and/or perlite comprising the other component; 2) substrates for large container plant production in the greenhouse that are usually $70 \%$ peat:30 \% perlite by volume; and, 3) substrates for outdoor container nursery plant production, which are typically 60 to $80 \%$ bark with various other materials, including recycled organic wastes, comprising the rest of the substrate. Bilderback et al. [46] indicated there is general agreement among U.S. researchers that alternative 
substrate components must be able to replace peat or bark by up to $30 \%$ or more (by volume) in substrates for container-grown plants.

Transportation costs, environmental considerations, and alternative uses will continue to put upward pressure on the price of peat and bark. A check of suppliers in Pierce County, Washington, indicated spring 2015 grower prices for Canadian sphagnum peat and fine-grade Douglas-fir bark for potting were \$101.28 and \$29.99 per cubic yard, respectively. These prices do not include delivery or sales tax and can vary with the quantity of material purchased.

\section{Other options for using AD fiber: composites, biofuels, and products derived from thermochemical processing operations}

Other important options that hold potential for supplanting or supplementing value-added use for AD dairy fiber consist of: a) production of composite materials, b) liquid biofuels, and c) products derived from thermochemical processing. Thermochemical processes include: combustion, gasification, pyrolysis, and hydrothermal operations (hydrothermal liquefaction and hydrothermal gasification), as presented in Figure 1 (which includes the uses discussed in Section 2). While combustion requires excess of oxygen, gasification is conducted in the presence of limited amounts of air. Pyrolysis and hydrothermal operations, conversely, occur in the absence of air. Potential products include: heat (for steam and/or electricity generation) in combustion, gases (for fuels and chemicals) in gasification, and liquids and solids (which is the case of pyrolytic bio-oil and charcoal) in the case of pyrolysis. This section describes some works that report potential uses of manure fiber and its corresponding AD fiber for producing these products. 


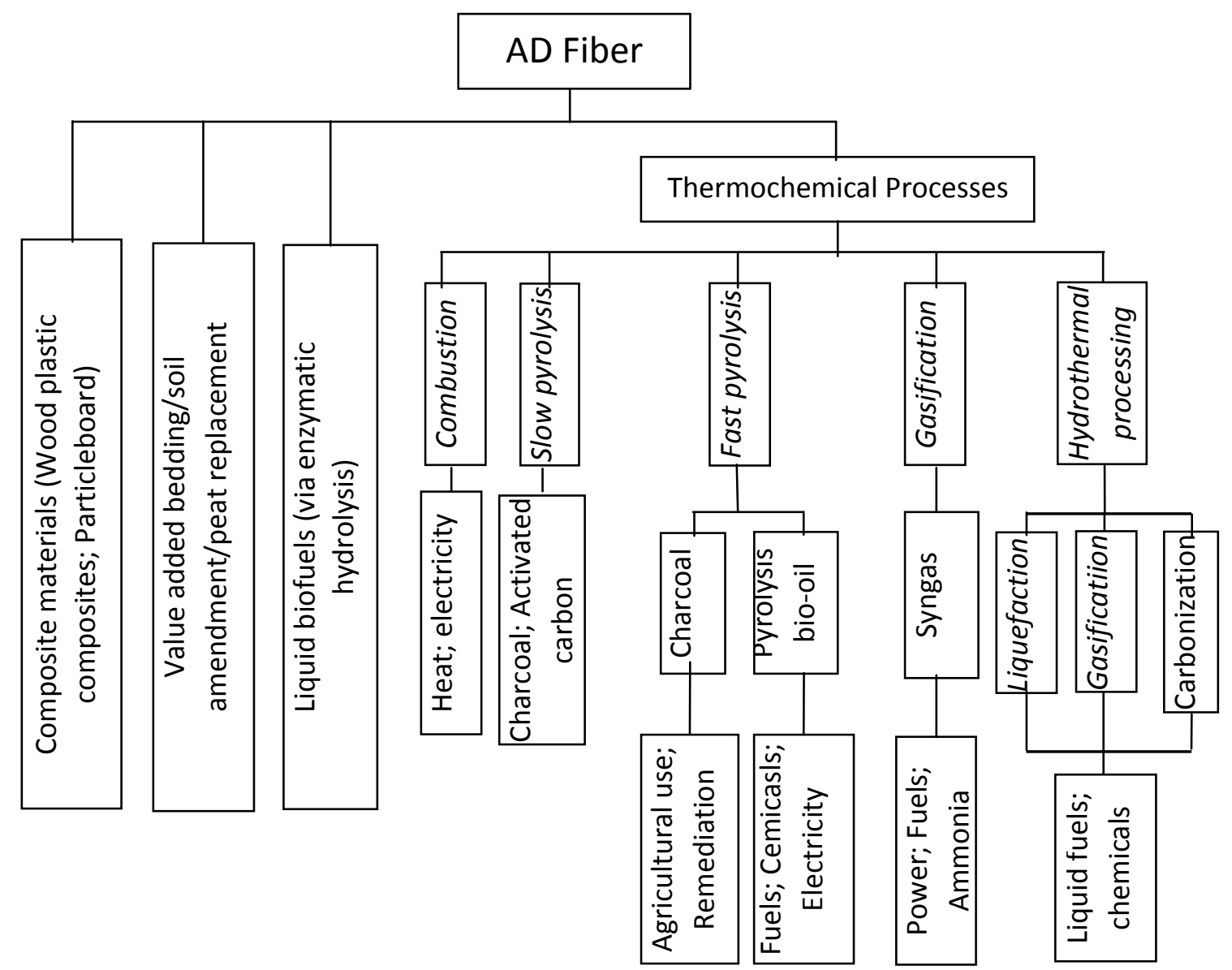

Figure 1. Options for adding value to anaerobically digested dairy fiber and some expected products.

\subsection{AD fiber as feedstock for composite materials}

Possibilities for producing composite materials using AD dairy manure have been reported by [66] (referred to by [67]), [68], [69] and, more recently, by Ferraz et al. [70]. Winandy and Cai [67] mentioned that the characteristics of AD fiber (e.g., size and geometry) could make it suitable to substitute either fiber for medium density fiberboard (MDF) or wood particles for particleboard. The authors found that particleboard panels produced with AD fiber, either alone or combined with wood particles, satisfy the requirements for $\mathrm{H}-1$ grade commercial particleboard [71] and MDF [72]. However, water sorption was high, which was attributed to the absence of wax in the formulations used for producing the composites. An associated publication [68] presented an economic analysis of the use of AD dairy fiber for manufacturing particleboard in the State of Wisconsin. Moreover, Dvorak and Hunt [69] have patented a method to produce composites from AD biomass, including AD dairy manure fiber, without adding resins, waxes, or sizing components. 
In the work of Ferraz et al. [70], the authors used AD fiber and, after a hot water extraction (HWE) process at 160 ${ }^{\circ} \mathrm{C}$ for $60 \mathrm{~min}$, they produced wood plastic composites (WPCs) via extrusion. The mass lost during HWE was 21.0 $\%$ of the original material. Figure 2 shows SEM pictures of AD dairy fiber and its corresponding HWE fiber, indicating morphological changes on the fibers. For extrusion, the formulation contained $58 \%$ of untreated or HWE AD fiber, 32\% HDPE (high density polyethylene), 3\% lubricant (zinc stearate), $2 \%$ zinc borate, and 5\% talc. WPCs produced with HWE AD fiber exhibited increased mechanical strength (36\%) and stiffness (30\%), and reduced strain at break (15\%) compared to composites produced with untreated AD fiber. Water sorption and thickness swelling were reduced by $39 \%$ and 36\%, respectively, after immersion in water for 98 days. Results evidence that a viable approach to enhance water resistance and mechanical properties of WPCS produced from AD fiber is by conducting an additional thermal treatment operation, which has also been found effective for other types of lignocellulosic materials $[73,74]$. Additional works on using the fibers in the whole dairy manure (i.e., without the AD prior step) for composites manufacture have been reported by [75, 76, 77]. These works could be of interest for comparison of the differences of using dairy manure fibers with and without the AD process.

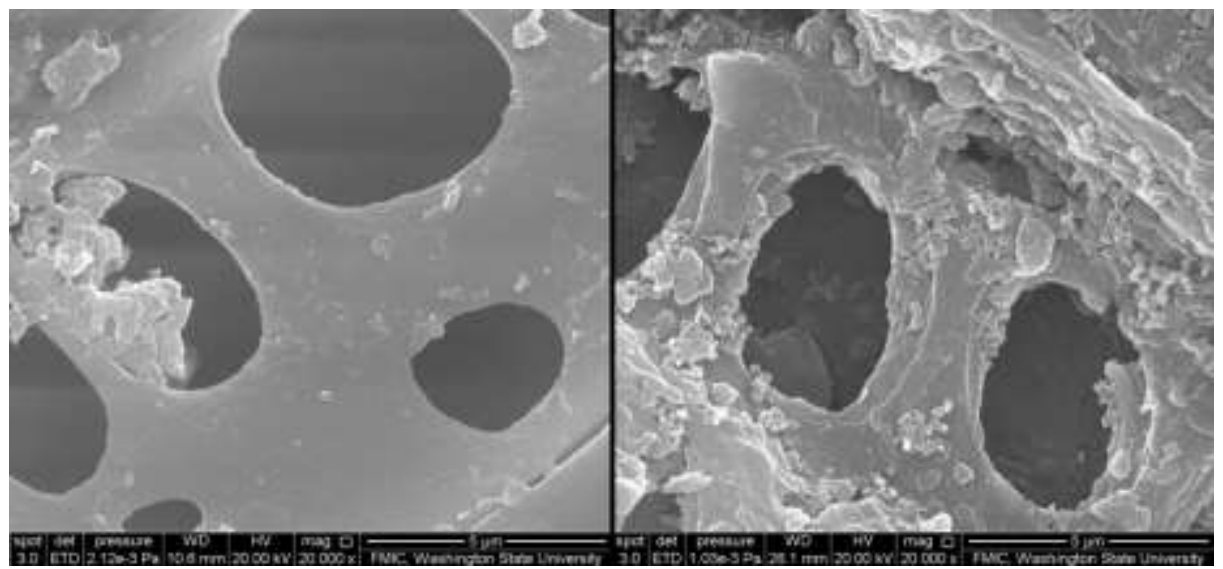

Figure 2. SEM images of $\mathrm{AD}$ fiber (left) and its corresponding hot water extracted fiber at $160^{\circ} \mathrm{C}$ for 30 min (right) (20000x) [70].

\subsection{AD fiber as feedstock for liquid biofuels}

AD dairy fiber has also been investigated as feedstock for producing liquid biofuels via enzymatic hydrolysis. Several studies have demonstrated that $\mathrm{AD}$ is capable of producing a fibrous solid with high cellulose and less hemicellulose content $[9,78,79,80]$. The compositional and structural changes of the AD fiber can be realized through the biological action of the microbial consortium that is rich in carbohydrate degraders including 
Clostridium and Bacteroidetes species [81]. After these changes, the AD fiber shows an ability to hydrolyze similar to other energy crops and residues such as switchgrass and corn stover. As in the case of dairy manure, the corresponding AD fiber can therefore be used for liquid biofuel production [12, 78, 79, 80, 82, 83, 84, 85].

Yue et al. [79] applied alkali pretreatment and enzymatic hydrolysis to convert AD dairy fiber into fermentable sugars for yeast ethanol fermentation, resulting in ethanol yield of $7.7 \%$ (w/w dry basis). In another work, a combination of sodium hydroxide and ammonium hydroxide pretreatment (at different concentrations) of AD dairy manure improved the delignification and enzymatic digestibility of the fiber for ethanol production [12]. These works show that, after $\mathrm{AD}$, additional effort could be required for efficient transformation of dairy fiber into sugars for biofuels

Zhong et al. [85] demonstrated a self-sustaining lignocellulosic biodiesel production system utilizing AD fiber and corn stover as co-feedstock for fungal lipid accumulation. A combined hydrolysis was applied to convert AD fiber and corn stover into mono-sugars, and then an oleaginous fungal strain-Mortierella isabelina was cultured on the mono-sugars to accumulate lipids for biodiesel production. The process generated $1 \mathrm{~L}$ biodiesel from $24 \mathrm{~kg}$ dry biomass (12 kg AD fiber and $12 \mathrm{~kg}$ corn stover). The fuel property analysis showed that the fungal-lipid based biodiesel is a good alternative to fossil diesel [86]. These studies delineated a new application of AD fiber for liquid biofuel production and offered an alternative route to establish an AD-based bio-refinery. Liao et al. [87]) reported an integrated farm-based bio-refining concept that implements $\mathrm{AD}$ as the base unit operation for power generation and $\mathrm{AD}$ fiber production (feedstock for ethanol fermentation), and integrates it with yeast ethanol fermentation and algal cultivation to create a closed-loop system for agricultural residue treatment and utilization [87]. They reported that approximately 118 million dry tons of animal manure from 1.2 million cattle farms in the U.S. could be mixed with 30 million dry tons of corn stover as the feedstock for the farm-based bio-refining operation. The system could be able to generate $11 \mathrm{GWh} /$ year of electricity, 1.7 billion gallons/year of ethanol, and $12 \mathrm{Mt} / \mathrm{year}$ of dry algal biomass. The potential for combining AD of dairy fiber with algae cultivation has also been assessed by Wang et al. [88], who demonstrated that $\mathrm{AD}$ dairy manure can effectively serve as a nutrient supplement for growing oil-rich green microalgae Chlorella sp. 


\subsection{Production of biochar from AD fiber for agricultural use and remediation}

Several works have been published on the production of biochar from AD dairy fiber, either for agricultural use or for remediation [89, 90, 91, 92, 93, 94, 95, 96, 97]. Streubel [89] and Streubel et al. [90, 91] investigated the use of biochar for P recovery in dairy lagoons and for amendment of five soil types in the State of Washington. The authors' evaluated four types of feedstocks (wood pellets, softwood bark, switchgrass straw, and AD fiber) for biochar production. In the case of $\mathrm{AD}$ fiber, the material was first pelletized into 5-mm diameter pellets and the pellets were subjected to pyrolysis at $500{ }^{\circ} \mathrm{C}$ for $4 \mathrm{~h}$ [91]. The biochar was then used for testing its capacity for sequestering $\mathrm{P}$ from dairy lagoons and to measure its impact on a sandy soil. The biochar reduced $\mathrm{P}$ in dairy effluent by $32 \%$. The sequestered $\mathrm{P}$ was predominantly in plant-available inorganic orthophosphate. The resulting fibercoated biochar increased C mineralization, sodium bicarbonate (Olsen), and water-extractable P levels. Results showed that biochar from AD can reduce P from dairy effluent and that the P-coated biochar may be a viable source of alternative $\mathrm{P}$ fertilizer. For soil amendment, the biochar was produced at $500{ }^{\circ} \mathrm{C}$ for $30 \mathrm{~min}$, using a continuous auger reactor [90]. The resulting biochar had a similar effect on soil than biochar produced from the other raw materials. The rate of biochar amendment and the change in $\mathrm{C}$ content of the soil showed a linear relationship. Soil pH increased with biochar amendments among all soil types and biochar feedstocks. Moreover, the feedstock was not a significant factor in raising $\mathrm{pH}$ or $\mathrm{C}$ content in the five types of soils the authors studied.

In another work, Inyang et al. [95] studied the ability of AD fiber biochar to sorb heavy metals from aqueous solutions. The biochar was produced at $600{ }^{\circ} \mathrm{C}$ for $2 \mathrm{~h}$ using nitrogen in a furnace. For the sorption tests, the authors

used a mixture of four heavy metals, $\mathrm{Pb}^{2+}, \mathrm{Cu}^{2+}, \mathrm{Ni}^{2+}$, and $\mathrm{Cd}^{2+}$, and lead $(\mathrm{Pb})$ only. Results showed that the biochar was effective for metals sorption and that its $\mathrm{Pb}$ sorption capacity was comparable to that of some commercial activated carbons.

An exhaustive work comparing several properties of charcoal produced from different types of feedstocks has been reported by [92]. Specifically, the work examined how feedstock and pyrolysis conditions impact some biochar properties that are of interest for agronomic use. The authors used bull manure with sawdust and dairy manure with rice hulls, besides corn stover, hazelnut shells, oak wood, pinewood, poultry manure with sawdust, grass clippings, paper waste, and food waste. The work also included AD manure and composted dairy manure. These materials were pyrolyzed at temperatures ranging from 300 to $600{ }^{\circ} \mathrm{C}$, using a slow pyrolysis reactor (Daisy reactor). 
Characterization of the resulting biochars included proximate analysis, elemental analysis, total metals, $\mathrm{pH}$, and organic C. Results showed that the highest ash content (up to $32 \%$ ) was found in animal manure (including both bull manure and AD dairy fiber) and waste biochars. Both volatiles and fixed carbon content varied in wide ranges, depending on the raw material and the conditions of the pyrolysis (carbonization) process. The $\mathrm{pH}$ of biochars also varied in a very wide range (from 4.5 to 11.6 ), depending on the feedstock. Biochars obtained from animal manure (including dairy manure, AD dairy manure, and composted dairy manure) had $\mathrm{pH}$ values above 7.5. The total $\mathrm{N}$, $\mathrm{P}$, $\mathrm{Ca}, \mathrm{Mg}$, and $\mathrm{Na}$ concentrations also varied greatly among the types of raw material. The authors found that it is difficult to predict the agronomic performance of biochars due in part to the variability of biochar properties. Therefore, they suggested that for a rational use of biochar it is important to define the limiting factors of a particular soil-crop-climate situation. A related work [97] studied how type of feedstock and pyrolysis temperature can affect the aromaticity and the condensation of these aromatic structures in biochar.

The impact of adding different amounts of biochar to a specific type of soil on corn growth (during a 46-day test) has been investigated by [93]. The authors produced biochar from several types of feedstocks (some also used by [92]), including AD dairy manure and poultry manure, at similar temperatures than in the work of [92]). As in the work of [92], the highest $\mathrm{pH}$ values were verified in biochar produced from animal manure. Both animal manures increased biomass yield of soil amended by up to $43 \%$ compared with soil without amendment. Plant growth was identified to be positively affected by biochar produced at temperatures of $500{ }^{\circ} \mathrm{C}$ and nutrient content was found as the main factor responsible for positive crop growth response. However, feedstock type had more effect on plant growth than pyrolysis temperature. According to the authors, post-treatment could be an approach for improving the properties of biochar for use under specific conditions of soil and crop type.

Kirk et al. [96] and Graydon et al. [94] have patented a method for producing biochar from AD fiber and using the resulting biochar for scrubbing hydrogen sulfide $\left(\mathrm{H}_{2} \mathrm{~S}\right)$ from biogas. The process consisted of heating the AD fiber into a tube furnace at temperatures ranging from 400 to $900{ }^{\circ} \mathrm{C}$ for $1 \mathrm{~h}$, using nitrogen as a carrier gas. Alternatively, the nitrogen for pyrolysis was humidified (using water) and AD fiber samples were heated at temperatures ranging from 500 to $850{ }^{\circ} \mathrm{C}$. The biochars were then tested to determine the corresponding $\mathrm{H}_{2} \mathrm{~S}$ absorption capacity. Results showed that: 1) the materials pyrolyzed at $400{ }^{\circ} \mathrm{C}, 500{ }^{\circ} \mathrm{C}$, and $700{ }^{\circ} \mathrm{C}$, without humidification, showed absorption capacities of $0.3,2.2$, and $4.1 \mathrm{mg} \mathrm{H}_{2} \mathrm{~S}$ per gram of biochar, respectively, which were considered low, 2) the addition 
of oxygen or air to the biogas that was tested increased the absorption capacity of biochar. In particular, it was observed that the addition of up to $2 \%$ of air increased the absorption capacity at the break through time (i.e., the time at which $\mathrm{H}_{2} \mathrm{~S}$ was detected in the gas after the biochar column absorption) to $35.8 \mathrm{mg} \mathrm{H}_{2} \mathrm{~S}$ per gram of biochar, 3) the addition of moisture to the carrier gas had an important effect on the absorption capacity of biochar. For example, AD fiber was pyrolyzed in the presence of humidified nitrogen at $850^{\circ} \mathrm{C}$ for $1 \mathrm{~h}$ (the humidification process was conducted by bubbling the gas through water at room temperature). The biochar was then tested for $\mathrm{H}_{2} \mathrm{~S}$ absorption capacity. The result showed that the absorption capacity increased to $330 \mathrm{mg} \mathrm{H}_{2} \mathrm{~S}$ per gram of biochar.

\section{Experiences on thermochemical processing of dairy manure and potential of using these with AD fiber}

While the focus of this review paper relates to the use of AD fiber, a discussion of thermochemical processing utilizing both the dairy manure and AD fiber is provided. There is a relatively rich experience on thermochemical processing of the non-digested dairy manure and the fibrous fraction of cow manure. Lessons learned from the whole manure studies can inform on potential uses for the AD fiber as well as conclusions for moving forward.

\subsection{Combustion for heat production}

Cow manure has been used as a fuel for heat production since ancient times as a substitute of wood fuel [98, 99, 100]. In the US, research on using dairy manure for heat production started apparently in the 1970s [101]. At that time, it was estimated that the cost of manure incineration could be similar to that of municipal solid waste incineration [102]. Renewed interest on using animal manure for fuel is due in part to the necessity of disposing large amounts of manure $[103,104,105,106]$. Studies on using dairy manure for heat production, as an alternative to $\mathrm{AD}$ or composting, have been reported in several publications $[103,104,105,106,107,108,109,110,111,112$, $113,114,115,116,117]$

A very descriptive report showing several fuel properties of dairy manure, options for thermochemical processing and experiences at pilot scale has been prepared by [104]. Some properties of dairy manure of interest for combustion and pyrolysis (particularly carbonization) have been investigated by [118]. Cantrell et al. [119] showed how thermogravimetric analysis can be employed for proximate analysis of livestock wastes (e.g., dairy manure). Sweeten et al. [105] compared the fuel properties of untreated dairy manure solids with the material after composting. The heating value decreased in composted material and in the materials that have been stored for a 
"long" time (e.g. eleven months). The relative ash content increased in the composted material, which explains in part the reduction of heating value. Low energy, high MC, and high ash content of dairy manure have been mentioned as factors that limit its use for combustion $[104,105,109,113,120]$.

Thermochemical processes could be more efficient if the manure MC were reduced by spontaneous evaporation (e.g., in dry environments) [121]. However, spontaneous evaporation is normally a slow process. Drying and pretreatment operations could help to increase the efficiency of thermochemical processing such as combustion. Pretreatment operations to improve the fuel value of dairy manure can include torrefaction [105]. According to the same author [105], for torrefaction, the fiber can be subjected to a washing and a drying step, followed by a briquetting process. Nevertheless, adding extra steps to the process and using extra energy for briquetting and water for washing could be a limitation for the economics of the process. Using extra water could also face environmental restrictions.

The combustion efficiency can be improved by using, for example, fluidized bed combustion units [108] or by cofiring with coal $[109,110,119]$. Co-firing with coal has been suggested since the 1970s [102] and seen as a method to compensate the difficulty of supplying high amounts of manure to operate large thermal power plants. Successful tests of co-firing of municipal solid waste with dairy manure have also been reported. A limiting factor is the presence of salts in manure, which could contribute to corrosion of boilers for combustion [103]. Co-firing can also be a strategy for reducing NOx emissions (co-firing $10 \%$ of dairy manure with coal can reduce NOx emissions by approximately $10 \%$ ) and for increasing financial returns to dairy operators [104]. However, co-firing may require reconfiguring the boilers used for combustion. Research showed that biomass fuels ignite at higher temperatures than coal despite the fact that biomass pyrolysis has lower activation energy [104]. The authors hypothesized that "the increased volatile content of biomass fuels carries away a portion of the heat required for biomass ignition thereby delaying the onset of ignition".

\subsection{Carbonization of dairy manure}

Although there are evidences that research on using charcoal (the term biochar is newer) for agricultural applications began approximately one century ago, as shown in works of [122] and later works of [123, 124, 125, 126], investigation on using charcoal from animal manure is relatively new. A work of [121] shows results on the 
pyrolysis of dairy manure, in which charcoal was one of the products. This charcoal was considered as a potential fuel. However, it possessed very high ash content $(\sim 50 \%)$, resulting in low calorific value (approximately half that of coal). This result explains in part why most current research on charcoal from manure has not considered energy (heat) production from charcoal. Massie [121] mentioned that no works on pyrolysis of manure were found prior to his publication. In fact, interest on employing dairy manure and its fiber for biochar production has been only sporadic. For example, Spokas et al. [127] reviewed literature on the agronomic benefits of using various types of charcoal and mentioned several publications that used manure for biochar production, but only three of them included dairy manure as feedstock.

Recent research on using dairy manure for charcoal has been conducted, for instance, in Japan [128], motivated by the necessity of looking for alternatives to composting and land filling of waste materials, which normally require large spaces. Four raw materials were used in the referred work: sugarcane bagasse, rice husk, animal waste (e.g., dairy manure), and human waste (treated municipal sludge). The pyrolysis (carbonization) was carried out in closed containers, at temperatures that varied from 250 to $800{ }^{\circ} \mathrm{C}$. The authors found that increments on pyrolysis temperature increased surface area, total carbon, ash content, and $\mathrm{pH}$ of charcoal, and the density of the product was not affected by the temperature. The yields of biochar produced from dairy manure were higher than those from the other raw materials. Surface area of the biochar obtained from dairy manure was larger than that of wood and sludge, but less than that of sugarcane bagasse. Ash content was highest in dairy manure biochar. Analysis of different properties allowed the authors to conclude that the biochars can be used as soil amenders or adsorbents. The raw material had considerable influence on the properties of the biochar, which has commonly been observed by other authors $[92,93,129,130]$. Cantrell et al. [128] compared properties of biochar produced from five types of manure (swine separated-solids, paved-feedlot manure, dairy manure, poultry litter, and turkey litter) produced at 350 and $700{ }^{\circ} \mathrm{C}$ for $2 \mathrm{~h}$, using an electric box furnace. Biochar produced from dairy manure presented the greatest volatile matter, $\mathrm{C}$, and energy content, along with the lowest ash, N, and S contents.

Cao and Harris [131], Cao et al. [132], and Xu et al. [133] reported works on the direct carbonization of dairy manure for biochar that was used for remediation. In the work of [131], the manure was dried and ground (the resulting particle size was less than $1 \mathrm{~mm}$ ) prior to carbonization. Biochar was produced using a muffle furnace at temperatures ranging from 100 to $650{ }^{\circ} \mathrm{C}$ under abundant air. However, a more effective pathway could be by 
grinding the produced biochar. Power consumption is greatly reduced if grinding is conducted on thermally modified biomass instead of grinding the biomass as received [73, 134, 135]. Cao and Harris [131] showed that surface area, ash content, and $\mathrm{pH}$ of biochar increased as the temperature in the furnace increased. As expected, combustion of the fiber occurred at temperatures higher than $350{ }^{\circ} \mathrm{C}$, thus leaving high amounts of ash. The biochar showed capability for absorption of $\mathrm{Pb}$ and atrazine from aqueous solution, which was confirmed by [132]. The charcoal produced from dairy manure using similar method was also effective for removing other types of heavy metals ( $\mathrm{Cd}, \mathrm{Cu}$, and $\mathrm{Zn})$ [133]. The mechanism that describes $\mathrm{Pb}(\mathrm{II})$ removal has been proposed by [136]. In a related work [137], biochar produced from dairy manure was suggested as an alternative to dairy manure for soil amendment as a method to reduce $\mathrm{P}$ in surrounding water.

Additional studies that explored the feasibility of using dairy manure biochar for remediation (stabilization of heavy metals) have been published by [138] and [139]. In the work of Uchimiya et al. [138], five different types of manure were employed: dairy, paved feedlot, swine solids, poultry litter, and turkey litter. The pyrolysis process was conducted using a Lindburg electric box furnace, as described by [140], at 350 and $700{ }^{\circ} \mathrm{C}$ for $2 \mathrm{~h}$ under nitrogen environment. The authors found that dairy manure (along with swine manure) is less effective for stabilization than the biochars produced from the other types of manure. Kinetic and adsorptive characteristics of biochar (produced from dairy manure) in metal ions have been reported by [139]. In the work of [139], biochar was produced at 400 and $600^{\circ} \mathrm{C}$ under nitrogen environment. Preliminary studies showed that the amount of $\mathrm{Cu}(\mathrm{II})$ ions adsorbed increased when smaller particles were used. Thus, the biochar was ground to obtain material with particle size between 0.420 and $0.600 \mathrm{~mm}$ and used for sorption tests of $\mathrm{Cu}(\mathrm{II}), \mathrm{Zn}(\mathrm{II}), \mathrm{Cd}(\mathrm{II})$ and $\mathrm{Pb}(\mathrm{II})$. The effectiveness of $\mathrm{Cu}(\mathrm{II}), \mathrm{Zn}(\mathrm{II}), \mathrm{Cd}(\mathrm{II})$ and $\mathrm{Pb}(\mathrm{II})$ ions removal increased by increasing the initial concentration of biochar and metal ion, $\mathrm{pH}$, as well as phase contact time. Maximum adsorption was observed in the $\mathrm{pH}$ range 5.0-6.0. The kinetics of adsorption was found to be pseudo second order with intra-particle diffusion as one of the rate determining steps.

\subsubsection{Biochar for soil amendment}

Several studies exploring the possibilities of using dairy manure biochar for soil amendment have recently been reported [92, 129, 130, 141, 142, 143]. Wang et al. [141, 142] produced biochar by mixing dairy manure with eucalyptus wood particles. The carbonization process was carried out using a rotating drum kiln at temperatures ranging from $250{ }^{\circ} \mathrm{C}$ to $550{ }^{\circ} \mathrm{C}$. The objectives of the works were to determine the phosphorous and nitrogen 
availability in biochar in the short and in the long term. For this, the biochar was extracted with $\mathrm{HCl}$ and the hydrolysable, extracted $\mathrm{N}$ (THN), was measured. The ratio of volatile C to THN was used as an indicator of whether net $\mathrm{N}$ mineralization or immobilization of $\mathrm{N}$ in biochar occurred. Thus, THN could be an adequate estimator of the labile $\mathrm{N}$ fraction in biochar in the short term [141].

Domene et al. [143] studied the effect of the pyrolysis conditions of dairy manure biochar for short-term ecological toxicity using basal soil respiration and collembolan reproduction tests. Results showed lack of toxicity at concentrations in the range of usual field biochar applications rates $(<20 \mathrm{t} / \mathrm{ha})$, indicating low short-term toxicity risk of the slow pyrolysis biochars used in the study. Singh et al. [129] evaluated the effect of biochar on soil in the conditions of nutrient-poor soils in Australia. The biochar was obtained from different plants and dairy manure via slow pyrolysis (using a Daisy reactor) at 400 and $500{ }^{\circ} \mathrm{C}$ with and/or without steam activation. As expected, biochar properties (e.g., pH, elemental composition, electrical conductivity (EC)) varied among feedstock types and relied on the pyrolysis conditions. However, the $\mathrm{pH}$ of dairy manure charcoal remained the same when the pyrolysis temperature was increased. Manure biochar presented the highest ash content but the lowest total C content. The manure based biochar also showed higher $\mathrm{N}, \mathrm{P}, \mathrm{K}, \mathrm{S}, \mathrm{Ca}, \mathrm{Mg}, \mathrm{Al}, \mathrm{Na}$, and $\mathrm{Cu}$ content than the wood based biochars. The activation process, on the other hand, had little effect on the properties of biochars. Manure biochar presented good to high liming potential.

An additional work that investigated the effect of cow manure biochar on maize productivity and nutrient uptake in sandy soils has been published by Uzoma et al. [144]. Dry dairy manure was used for carbonization at $500{ }^{\circ} \mathrm{C}$ for 5 $\mathrm{h}$ using a muffle furnace. The resulting biochar was ground for blending with sandy soil for maize production under greenhouse conditions. It was observed that biochar promoted positive effects on total height and number of leaves at different growth stages of maize. Maize grain yield was increased by up to $150 \%$ when biochar was applied to soil (compared to control without biochar addition). The results were attributed to the presence of nutrients in cow manure biochar.

The Wisconsin Department of Agriculture, Trade and Consumer Protection [145] has provided information about a project for using dairy manure for producing biochar, gases, and bio-oil via slow pyrolysis, although the bio-oil was not a target product from the process. The bio-oil resulting from the process was consumed in the process as a fuel. 
Additionally, studies to determine thermodynamic parameters related with the pyrolysis of dairy manure and other materials (rice straw, rice bran, and chicken manure) has been carried out by [146]. The raw materials were dried and ground to particle size less than $0.154 \mathrm{~mm}$ (100 mesh) and used for thermogravimetric analysis (TGA). TGA aimed at determining the activation energy of the pyrolysis of each biomass constituent (i.e., cellulose, hemicellulose, and lignin in the fiber). Biochar was produced using a muffle at temperatures ranging from 100 to $700{ }^{\circ} \mathrm{C}$ for $6 \mathrm{~h}$ for comparison of results obtained via TGA. Results showed that the activation energy was not very different among biomass constituents independent of the feedstock, but in the case of manure, values were visibly affected by the presence of minerals. TGA has also been used for studying the mechanism of the pyrolysis process of cattle manure [147] and for studying the biological stabilization process of this material [148].

\subsection{Production of activated carbon}

Qian et al. [149, 150] explored the feasibility of using the fiber after dairy manure composting for producing activated carbon. After drying, the fiber was ground and subjected to a one-step carbonization and activation process, using chemical activation by zinc chloride. Prior to pyrolysis, the fiber was impregnated with zinc chloride solution. The tests were conducted in a horizontal tubular furnace under nitrogen flow of $300 \mathrm{~mL} / \mathrm{min}$. The pyrolysis temperature ranged from 400 to $900{ }^{\circ} \mathrm{C}$ with various retention times. The resultant activated carbons were characterized by nitrogen adsorption-desorption (at $77 \mathrm{~K}$ ). The authors observed that dairy manure compost can adequately be used for activated carbon using zinc chloride. Yields of activated carbon can be up to $47 \%$.

\subsection{Pyrolysis for bio-oil production}

Pyrolysis processing of dairy manure intending to optimize the yields of liquids (pyrolytic bio-oil) has been reported, to the best of our knowledge, only by Garner and Smith [151]. The authors used livestock waste (steer manure), which was dried, ground, and subjected to pyrolysis. The process was conducted at atmospheric and low pressure. Optimum operating conditions were established by the criteria of maximizing yield of liquid organic products and minimizing the yield of carbonaceous solid residue. Low pressure and a maximum temperature of 400$500{ }^{\circ} \mathrm{C}$ showed the best results. A multiple condensation system was employed to collect the condensable fractions from the pyrolysis products. This setup approximated a continuous run. The material from this run was analyzed by a classical organic separation scheme. Typical yields of products are presented in Table 2 . 
Table 2. Typical yields of products of the pyrolysis of steer manure (dry weight basis) [151].

\begin{tabular}{|l|l|}
\hline Char & $35.7 \%$ \\
\hline Ash & $9.2 \%$ \\
\hline Carbonaceous residue & $26.5 \%$ (by difference) \\
\hline Low-boiling organics & $7.3 \%$ \\
\hline Tarry volatile organics & $14.2 \%$ \\
\hline Reaction water & $16.7 \%$ \\
\hline Noncondensable gases & $26.1 \%$ (by difference) \\
\hline
\end{tabular}

Analysis of the liquid fraction showed that it was constituted by a wide variety of alcohols, aldehydes, ketones, acids, amines and phenols as well as poly-functional compounds, but none was present in sufficient concentration for profitable separation. Therefore, pyrolysis of cattle feedlot wastes was found uneconomical in comparison with incineration. However, it was stated that economic pyrolysis might be feasible if the fresh manure were allowed to spontaneously dry in an arid climate.

It is important to mention other works on "pyrolysis" of livestock wastes (cattle manure) that have been conducted at temperatures that today are more frequent for gasification. For instance, [152] pyrolyzed cow manure at $800{ }^{\circ} \mathrm{C}$, using both wet and pre-dried materials, after grinding (40 mesh particle size). It is evident in this work that the objective was to maximize gases production instead of liquids (pyrolysis bio-oil). However, the authors mentioned that a liquid fraction was recovered through a simple condensation system, although no characterization of this liquid was reported.

\subsection{Thermal gasification}

Thermal gasification has been perhaps the most studied thermochemical process (in terms of the amount of publications) intending to transform dairy manure into value-added byproducts (e.g., fuel gases and liquids), as reported in a number of works $[153,154,155,156,157,158,159,160,161,162,163,164,165,166,167,168,169$, 170, 171, 172, 173, 174, 175, 176, 177, 178, 179]. However, as stated by the Midwest Energy Research Center 
[180], no operational farm-scale gasification systems have been identified in the United States but research has been conducted only at laboratory or pilot scale.

Interest on gasification of manure started during the 1970s. Whetstone et al. [102] (p. 68) mentioned that no experimental results on high temperature manure gasification were reported prior 1974. At that time, it was presumed that results of manure gasification could be similar to results from coal gasification, "with appropriate allowance for manure's high ash content and low heating value" [102]. A review carried out by Huffman et al. [163] mentioned that an initial project on gasification of cattle manure was developed in 1971 at Texas Tech University. As a result, a number of works on gasification of dairy manure were conducted during the 1970s [153, 154, 155, $161,162,163,164]$. Engler et al. [155] evaluated a concept for gasification of feedlot manure considering the advantages of simultaneously producing gases (which were envisioned that could be used for power generation, raw material for ammonia synthesis, or raw material for methanol production) and ash by-product potentially usable as a fertilizer. The conceptual design was based on a plant with capacity of $1000 \mathrm{t} / \mathrm{d}$ of manure (50\% of MC). The main sections of the proposed concept included three major steps: preparation, gasification, and gas cleanup. Results showed that only large scale facilities could be attractive from an economic point of view.

In the US, experimental studies on gasification of dairy manure apparently started with a work of Halligan et al. [161], who investigated the potential of using cattle feedlot manure for producing ammonia synthesis gases in a bench scale fluidized-bed reactor. The range of temperatures tested was from 677 to $816^{\circ} \mathrm{C}$. Although relatively high yields of gas were reported, additional desulfurization and reformation processes were suggested to make the gas suitable for the synthesis of ammonia. The potential ammonia production of the reactor could reach $0.5 \mathrm{t}$ of $\mathrm{NH}_{3}$ per t of dry, ash-free animal manure processed. A scaled-up version of the reactor described by [161], able to process $450 \mathrm{~kg} / \mathrm{day}$ of manure, was further manufactured. The reactor was a counter-current fluidized one with airsteam mixtures to fluidize and gasify the manure. This pilot plant was used by other authors [153, 162, 164], who also studied options for producing ammonia synthesis gases from cattle feedlot manure. Results confirmed the feasibility of producing ammonia synthesis gases. In addition, the results showed the feasibility of scaling-up the process for producing medium heating value gas potentially suitable as a fuel. Ethylene was suggested as an additional gas that could be produced from cattle manure gasification [164]. The reactor used by the authors allowed 
production of ethylene that ranged from 21 to $70 \mathrm{~g}$ per kg of dry, ash-free manure, depending on the conditions of the process.

Studies conducted by $[168,169]$ provided information on the effect of gasification temperature, as well as gas velocity and feedstock particle size on gases composition, yield, and high heating value. For the experiments, the authors used a $23 \mathrm{~cm}$ internal diameter fluidized bed reactor. The feedlot manure (80\% MC) was dried to $8 \% \mathrm{MC}$ prior to gasification. Particle size ranged from 2 to 40 mesh and the feeding rate was varied from 10 to $20 \mathrm{~kg} / \mathrm{h}$. Results showed that temperature is the factor that most affects the properties and yield of the gas produced from feedlot manure since both yield and heating value increased as gasification temperature was augmented. Particle size had a marginal impact on the composition and heating value of the produced gas, while the superficial gas velocity was shown not to affect composition and heating value of the produced gas. The heating value of the gases was up to $19.5 \mathrm{MJ} / \mathrm{Nm}^{3}$. A mathematical model was later proposed for the gasification process of feedlot manure in the fluidized-bed reactor [170]. Kunzru and Ali [164] also provided data on the effect of particle size of bovine waste on gas yield and properties. Gas yields increased with temperature and varied from 0.5 to $0.65 \mathrm{Nm}^{3} / \mathrm{kg}$ of raw material. However, the heating value of the gas was lower (up to $13 \mathrm{MJ} / \mathrm{Nm}^{3}$ ) than in the case of the works of [170].

Fan and Walawender [156] mentioned that one of the problems of using fluidized-bed reactors for biomass gasification is the formation of agglomerates or "clinkers" from the sand used for the fluidization process. The authors proposed utilizing an anti-agglomerating material to prevent deterioration of the fluidizing sand. The effectiveness of the innovation was proven by gasifying different types of feedstocks, including feedlot manure. Pian and Yoshikawa [171, 172], on the other hand, proposed a gasification technology referred to as MEET (Multi-staged Enthalpy Extraction Technology). The process used a high-temperature, rapid devolatilization process "to enhance the volatile yields from the fuel and to improve the gasification efficiency. A high-temperature pebble bed filter" was "used to remove the slag and particulates from the synthetic fuel gas. Finally, a novel regenerative air heater" was "used to supply the high temperature air for use to achieve rapid pyrolysis in the gasifier." The authors mentioned that the system worked adequately with different raw materials, including partially composted cow manure. The portability of the system was also claimed as an important characteristic of the innovation. Additional information on the MEET process characteristics and operation has been provided by Young and Pian [179], who also conducted gasification of dairy manure. Results indicated that gasification efficiencies can reach up to 65-68 \%, 
depending on the gasifier operating configuration. The authors suggested that the gases could be used for producing electricity or heat in the farms.

Studies on gasification of dairy manure combined with poultry litter and on co-gasification of dairy manure with coal have been conducted by Priyadarsan et al. [173, 174]. The experimental work was conducted using a $10 \mathrm{~kW}$ (thermal) fixed-bed counter-current atmospheric pressure gasification reactor. Gasification of dairy manure produced low energy content gas $\left(4.4 \pm 0.4 \mathrm{MJ} / \mathrm{m}^{3}\right)$ and an average product gas composition (dry basis) of $\mathrm{H}_{2}$ : 5.8 $\pm 1.7 \%, \mathrm{CO}: 27.6 \pm 3.6 \%, \mathrm{CH}_{4}: 1.0 \pm 0.5 \%, \mathrm{CO}_{2}: 6.7 \pm 4.3 \%$, and $\mathrm{N}_{2}: 59.0 \pm 7.1 \%$. Co-gasification of dairy manure with coal, on the other hand, showed that there were no variations on the product gases in terms of composition, irrespectively of the particle size of the raw material or air flow rate. However, higher oxygen content in biomass resulted in slightly higher $\mathrm{CO}_{2}$ content in the gases. The heating value of the gases was in the range of 4.5 to 5.1 $\mathrm{MJ} / \mathrm{kg}$. The results suggested that blending manure with coal does not affect the heating value of the gas product. Therefore, it was found that it is feasible to co-gasify animal waste-based fuels (high-ash, low-energy content), such as feedlot and chicken litter, with coal.

Other works on gasification of dairy manure have been published by [157, 158, 159, 160, 175]. These authors have used an adiabatic, fixed bed gasifier, with air and steam as oxidizers. $\mathrm{H}_{2}$ in gases was reported to be up to $28 \%$. A model to predict the composition of the gases based on the biomass characteristics was additionally provided. An important study on the life cycle assessment (LCA) of greenhouse gas (GHG) emissions of feedlot manure practices, comparing land application and gasification of feedlot manure, has been prepared by [178]. The publication showed that the net GHG emissions in land application was $119 \mathrm{~kg} \mathrm{CO}_{2}$ eq for $1 \mathrm{t}$ of dry feedlot manure, which was much higher than the $-643 \mathrm{~kg} \mathrm{CO}_{2}$ eq for $1 \mathrm{t}$ of dry feedlot manure that resulted from gasification of manure. Therefore, gasification of feedlot manure appeared a more promising approach to reduce GHG emissions than land applications. This work has been further complemented by studies on the design of the process and by providing more insight on the benefits of gasification compared with land application of manure [176, 178].

\subsection{Hydrothermal processing}

This section reviews works in which dairy manure has been used for producing energy (e.g., synthesis gas) and other products (e.g., chemicals) while manure is still in a water slurry. The operations for processing high MC dairy 
manure are referred to as hydrothermal processes. Hydrothermal processing involves three possible operations: hydrothermal liquefaction, hydrothermal gasification (also known as wet gasification), and hydrothermal carbonization. While hydrothermal liquefaction (water at subcritical conditions) of biomass intends to convert biomass into liquid fuels and chemicals, hydrothermal gasification (either under subcritical or above critical conditions) intends to transform biomass into gases, usually by using a catalyst [167, 181]. A variation of this process is hydrogasification, in which hydrogen is used and a catalyst is not required. As in the case of gasification, studies on the hydrothermal processing of dairy manure started during the 1970s, although the interest on this process, using other types of biomass, started in the 1940s [182]. Since drying can be expensive, direct use of high MC manure (without adding extra water) could positively impact the efficiency of the thermal conversion operation.

\subsubsection{Hydrothermal liquefaction}

Studies on hydrothermal liquefaction of dairy manure have been reported by, for example, [183, 184, 185]. Fu et al. [183] processed bovine manure at temperatures of 330,380 , and $425^{\circ} \mathrm{C}$ and pressures of 1500 to 3000 psi ( 10-20 MPa). Part of the bio-oil produced was recycled for the hydrothermal process in the presence of a Co-Mo catalyst. The catalyst increased the yields of oil and the temperature was the parameter that most affected the properties of the bio-oil. Mass spectrometry analysis of oil produced at $380^{\circ} \mathrm{C}$ suggested that the main compounds in the oil were alicyclic hydrocarbons, $\mathrm{N}$-containing heterocyclic compounds, and alkalyl phenols $\left(\mathrm{C}_{8}-\mathrm{C}_{18}\right.$ range). Cow manure with MC up to $35 \%$ was evaluated and found as an acceptable feedstock, without the necessity of adding extra water to the process.

Yin et al. [184] studied the effects of different processing parameters (e.g., temperature, pressure, residence time, and manure to water mass ratio) on the yields of the bio-oil obtained via hydrothermal liquefaction. The process consisted of grinding dairy manure without removing moisture (initial MC was $76 \%$ ) and subsequently subjecting it to a subcritical hydrothermal liquefaction process using a $1.8 \mathrm{~L}$ Parr reactor. Temperatures were varied from 270 to $350{ }^{\circ} \mathrm{C}$, the manure to water mass ratio was changed from 0.25 to 2 , and the time was varied from 0 to 40 min (isothermal conditions only). $\mathrm{NaOH}$ was added to the reactor. The bio-oils' properties were compared with those of gasoline, ethanol, biodiesel, and pyrolysis bio-oil. The yield of bio-oil was up to $49 \%$, which was obtained at 310 ${ }^{\circ} \mathrm{C}$, with $\mathrm{CO}$ as process gas, residence time of $15 \mathrm{~min}$ (at isothermal conditions) and manure to water ratio of 0.25 (mass/mass). The high heating value (HHV) was estimated (based on elemental composition) to be approximately 
35.5 MJ/kg on average. Results of the characterization of the bio-oil also showed that it contained function groups of poly-alcohols, carboxylic acids, phenol derivatives, and alpha,beta-unsaturated ketones. The bio-oil did not present $\mathrm{C}_{4}-\mathrm{C}_{15}$ constituents, the major components of gasoline and diesel. Non-polar compounds were toluene, ethyl benzene and xylene. These findings suggested that upgrading steps are required for further use of the bio-oil (obtained from dairy manure via hydrothermal liquefaction) as liquid transportation fuel. In another study [185], the authors presented a concept for waste treatment and simultaneous hydrothermal liquefaction of manure. The manure was first dried; then, deionized water was added (4:1 mass/mass water to manure ratio) for the hydrothermal treatment. The temperature in the reactor was varied from 250 to $350{ }^{\circ} \mathrm{C}$ (pressures from 5.1 to $20.5 \mathrm{MPa}$ ), for 15 min, with varying amounts of $\mathrm{Na}_{2} \mathrm{CO}_{3}$ as catalyst. $\mathrm{CO}$ was used as process gas. The energy efficiency of the process was up to $\sim 68 \%$ and the HHV of the bio-oil obtained was up to $32 \mathrm{MJ} / \mathrm{kg}$. Chemical oxygen demand (COD) of the dischargeable slurry, on the other hand, was up to $75 \%$.

\subsubsection{Hydrothermal gasification and hydrogasification}

Hydrothermal gasification of dairy manure has been conducted by [167, 186, 187, 188]. Elliot et al. [186] carried out wet gasification in a continuous process in fixed-bed catalytic tubular reactors. The manure slurry used in the process was ground to 60 mesh. The wet gasification process was performed at temperatures from 330 to $360{ }^{\circ} \mathrm{C}$ and $21 \mathrm{MPa}$, using ruthenium metal catalyst. No other oxidizer or reagent than water was added. The analysis of the produced gas was conducted via GC and the liquid effluent was analyzed for chemical oxygen demand (COD) and $\mathrm{pH}$, with spot checks for ammonia, inorganic anions (principally chloride and sulfate), and trace metals. The authors concluded that although good gas production was demonstrated, the presence of trace compounds in biomass caused some processing difficulties. Therefore, careful monitoring and control of feedstock trace components (e.g., calcium, magnesium, sulfur, and phosphorus) are critical for maintaining long-term operability and catalyst activity.

Matsumura et al. [167] reviewed the status of wet gasification in near- and supercritical water conditions for processing high MC biomass. In addition, the authors compared some results on hydrothermal gasification of several feedstocks, including dairy manure.

The work of Ro et al. [187] assessed the feasibility of wet gasification for treatment/energy conversion of manure (swine, dairy, paved and unpaved feedlot, and poultry), municipal solid waste (MSW), and raw sludge. The study was based on the analysis of energy production potentials and end products composition. The work also compared 
relevant costs and benefits of first-generation wet gasification technology to anaerobic lagoon animal manure management technology. The authors observed that high MC materials (swine and dairy manure, and sewage sludge) can be directly gasified (using hydrothermal gasification) to produce an energy rich gas; however, additional water is required for poultry litter, MSW, and feedlot manures to make the feedstock suitable for pumping. Results suggested that municipal solid waste and unpaved feedlot manure would not generate positive energy balance if an efficient heat recovery system ( $90 \%$ efficiency) is not added to the process. The net energy was higher in wet gasification of swine manure, while MSW and unpaved feedlot manure produced the lowest. Yakaboylu et al. [188], on the other hand, investigated the equilibrium partitioning of elements on the basis of compounds and phases in supercritical wet gasification of a mix of pig and cow manure. The interval of temperatures investigated was from 100 to $500^{\circ} \mathrm{C}$ and $24 \mathrm{MPa}$. In addition, the effects of pressure and water fraction on main product gases were explored. Results of the modeling process suggested that hydrothermal gasification above $340{ }^{\circ} \mathrm{C}$ would be appropriate under equilibrium conditions.

An alternative process to hydrothermal liquefaction and hydrothermal gasification is hydrogasification, in which manure reacts with hydrogen at temperatures similar to those used for hydrothermal gasification, but using higher pressure, and without the necessity of catalysts. The gas produced is rich in methane. This process was used by Kiang et al. [189], who proposed to produce synthetic natural gas, without the need of methanation steps. Both batch and continuous processes were investigated, showing that the manure in the continuous reactor was more reactive. The process was conducted at $550^{\circ} \mathrm{C}$ and pressure of approximately $11 \mathrm{MPa}$. The heating value of the produced gas was approximately $37.7 \mathrm{MJ} / \mathrm{m}^{3}$. It was found that no tars or oils were produced from manure hydrogasification. A review on economic analyses of the hydrogasification process has been presented by Kreis [190].

\subsubsection{Hydrothermal carbonization}

Hydrothermal carbonization has been suggested as a process for managing P content in cow manure. Dai et al. [191] used wet cow manure ( $85 \% \mathrm{MC}$ ) for biochar production using autoclaves that operated at $200^{\circ} \mathrm{C}$ for $4,6,8,10,12$, and $24 \mathrm{~h}$. Results indicated that hydrothermal processing retains $\mathrm{P}$ (as observed from the relative increase of P in thermally treated manure). Moreover, the retained P presented lower levels of Water-extractable P (WEP) and Mehlich-3-extractable P (MEP), which was attributed to the effect of hydrothermal treatment. Thus, hydrothermal carbonization has been suggested as a viable technology for immobilizing P in cow manure. 


\section{Opportunities for adopting thermal operations for adding value to AD fiber}

The literature review presented in the previous sections shows that there is a relatively rich experience on using thermochemical processing of dairy manure for producing heat, synthesis gases, or biochar. However, the experience on using AD dairy fiber is more limited. Most of the research has been conducted at laboratory scale and only a few works were conducted at pilot scale. Although adapting these experiences in current dairy farms (that have implemented $\mathrm{AD}$ ) for processing $\mathrm{AD}$ fiber does not seem a straightforward process, thermochemical processing offers a promising pathway for adding value to $\mathrm{AD}$ fiber, especially if integration of these technologies with $\mathrm{AD}$ is performed. Some obstacles and opportunities for adopting thermochemical processes for livestock residues treatment have been discussed by [192]. This section discusses ideas on why thermochemical operations offer potential for transforming AD fiber into value-added products beyond the present focus on soil amendments and peat/nursery industry.

Possible thermal processes that could be employed for adding value to AD fiber are: fast pyrolysis, hydrothermal processing, combustion, production of fuel pellets, slow pyrolysis for biochar production, and gasification. Both fast pyrolysis (for bio-oil production) and hydrothermal processes are at development stages and, in the case of the pyrolysis bio-oil, refining operations that could allow for its use/upgrading are not commercially available. Combustion, on the other hand, would not be attractive from an economic point of view because using the heat produced in the dairy farm could be possible at a limited scale only. Heat, in fact, may result in a low value-adding strategy due to seasonal uses of heat (at least in temperate regions). In addition, as discussed in previous sections, the high ash content could hinder the operation of systems designed for operating with other types of biomass. Our literature review suggests that no works have been conducted on using AD fiber for combustion.

Research on using manure fiber for pellets production (e.g., for home heating) has not been reported in the literature. Lack of works on combustion and pellets production using AD fiber can in part be justified by the potential problems associated with the use of high ash content $\mathrm{AD}$ fiber. Tests we have conducted using a LECO CHN equipment $[193,194]$ showed that the ash content in $\mathrm{AD}$ fiber can be as high as $26 \%$ (in dry basis) and nitrogen 
content (in dry and ash free basis) can reach up to 4.4\%. Ash content directly affects the combustion process and the quality of fuel pellets. The Pellet Fuel Institute' standard [195] has established that high quality (premium) pellets should contain very low ash content $(<1 \%)$. Therefore, using AD fiber for fuel pellets is greatly limited by ash content. The production of biochar via slow pyrolysis (carbonization), on the other hand, needs to be accompanied by additional processes in which the biochar has to be produced/modified to comply with characteristics required for specific uses such as agriculture and/or remediation. Therefore, this option sounds attractive only if the dairy farm is committed to including new business models in which biochars designed and produced for specific purposes are targeted products.

\subsection{Gasification of AD fiber}

The possible limitations of combustion, fast pyrolysis, hydrothermal processing, carbonization, and pelletization can be avoided if the dairy farm adopts thermochemical operations able to produce a product the farmer is more familiar with. Undoubtedly, this product is methane (biogas). Since dairy farmers that currently produce biogas via AD have a long experience on managing/using biogas and infrastructure for using this fuel is available, the ideal business model should be designed to improve the yields of biogas in the dairy farms by using the fibers after AD. From this point of view, currently, thermal gasification presents the best perspectives.

Synthesis gases produced via thermal gasification are a mixture of $\mathrm{CO}, \mathrm{H}_{2}, \mathrm{CO}_{2}, \mathrm{CH}_{4}$, and other gases in less amounts. Interest in using syngas for methanation $\left(\mathrm{CO}+3 \mathrm{H}_{2}=>\mathrm{CH}_{4}+\mathrm{H}_{2} \mathrm{O} ; \Delta \mathrm{H}^{0}=-206 \mathrm{~kJ} / \mathrm{mol}\right)$ to synthetic natural gas (SNG) has been reported in several studies [196, 197, 198]. However, this approach, while technically feasible, may be limited by the necessity of using expensive catalysts and the requirement of cooling the reactors due to the highly exothermic methanation process $[198,199]$. The use of such catalysts can be avoided if the synthesis gas produced via thermal gasification of the dairy fiber is added to the AD process inside the dairy farm to increase the yields of methane. Josse and Benedek [200] have patented a method for adding syngas to the AD process. The only requirement for adding syngas to the digester is that the temperature of the syngas needs to be lowered. Ideally, the heat released during the cooling process should be used for drying the fiber after AD.

Figure 3 shows a simplified diagram of the possible integration of AD with thermal gasification in dairy farms. The proposed concept shows that this integration can also allow for a better utilization of another main gasification 
byproduct, charcoal, and for heat recovery. The charcoal could be prepared and/or activated to comply with specific requirements for cleaning the produced syngas and for biogas scrubbing. The hot gases, on the other hand, can be used for drying the $\mathrm{AD}$ fiber and reduce the moisture content. The condensed moisture can also be recovered for several uses in the dairy farm. Moreover, the high ash content of AD fiber is not a limitation in the proposed concept if updraft gasifiers are used. Updraft gasifiers are suitable for feedstocks with high ash (up to $25 \%$ ) and high MC (e.g. up to $60 \%)[201])$.

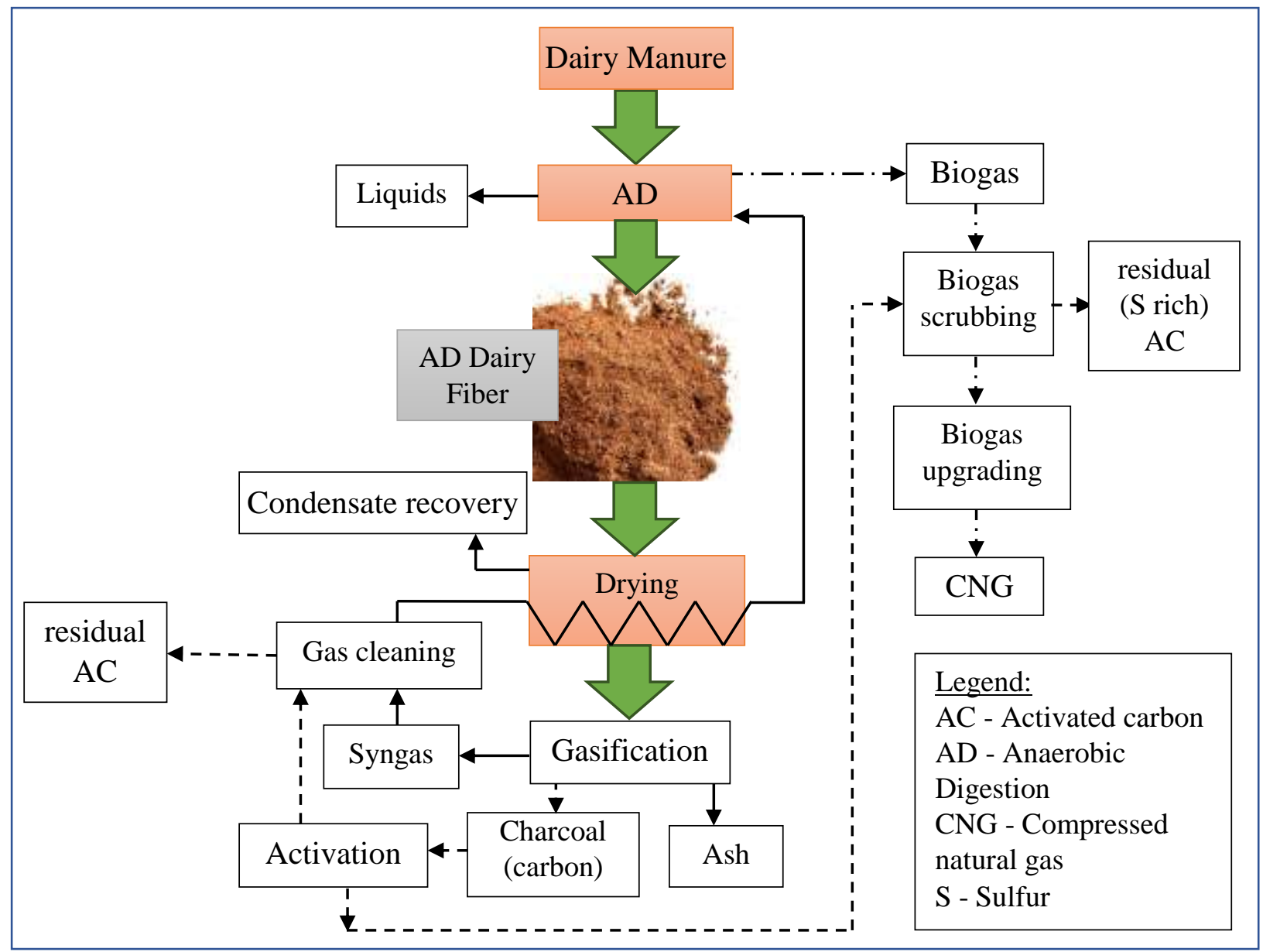

Figure 3. Scheme of the proposed integration of manure $\mathrm{AD}$ with thermal gasification of $\mathrm{AD}$ fiber for increasing biogas yields and using bioproducts (e.g., char).

\section{Conclusion}

There exists a rich experience, although mostly at laboratory scale, on using dairy manure and the corresponding anaerobically digested fiber for producing an array of products through non-thermal and thermal processes. The 
products identified include: peat moss substitute, fertilizers, charcoal (via carbonization), sugars for biofuels, syngas (via gasification), wood composites, bio-oil from both fast pyrolysis and hydrothermal operations. Fertilizers and peat moss substitutes produced form AD fiber have reached commercial level. The production of wood composites appears promising if additional thermal treatment is conducted to reduce the natural hygroscopicity of the fiber and, thus, improve composite water resistance. However, this topic deserves further study to evaluate the economics of the process. Thermochemical operations offer options for an integrated use of AD fiber. Among thermochemical processes, both fast pyrolysis (for bio-oil production) and hydrothermal processes are at development stage. Moreover, refining/upgrading operations for pyrolysis bio-oil are not commercially available, thus limiting fast pyrolysis of $\mathrm{AD}$ fiber. Combustion would not be attractive from an economic point of view because using the heat produced in the dairy farm could be possible at a limited scale only. The high ash content could hinder operating equipment designed for other types of biomass and for fuel pellets production. Production of biochar needs to be accompanied by additional processes in which the biochar should be produced/modified to comply with characteristics required for specific uses such as agriculture and/or remediation. Therefore, this option sounds attractive if the dairy farm is committed to including new business models in which biochars designed and produced for specific purposes are targeted products. The possible limitations of combustion, fast pyrolysis, hydrothermal processing, carbonization, and pelletization can be avoided if the dairy farm adopts thermochemical operations able to produce a product the farmer is more familiar with, which is the case of biogas. Thus, thermal gasification offers important perspectives. Dairy farmers currently produce biogas via $\mathrm{AD}$ and have a long experience on managing/using biogas. Infrastructure for using this fuel is also available and ready. Therefore, the ideal business model could be designed to improve the yields of biogas in the dairy farms by using the fibers after AD.

\section{Acknowledgement}

This research was supported by funding from the USDA National Institute of Food and Agriculture, Contract \#20126800219814, and Biomass Research Funds from the Washington State University Agricultural Research Center.

\section{References}

[1] USDA United States Department of Agriculture, 2012 Census of Agriculture, Census Volume 1, Chapter 1: U.S. National Level Data. Retrieved December $23^{\text {rd }}$, 2015, from: http://www.agcensus.usda.gov/Publications/2012/Full_Report/Volume_1,_Chapter_1_US/ 
[2] Al Seadi T, Rutz D, Prassl H, Köttner M, Finsterwalder T, Volk S, Janssen R. Biogas Handbook, published by University of Southern Denmark Esbjerg, Esbjerg, Denmark, 2008. Retrieved December $20^{\text {th }}$, 2014, from: http://www.lemvigbiogas.com/BiogasHandbook.pdf

[3] Yorgey G, Frear C, Kruger C, Zimmerman T. The Rationale for Recovery of Phosphorus and Nitrogen from Dairy Manure. WSU Extension Factsheet, Pullman, WA, 2014.

[4] ICUSD. National market value for anaerobic digestion products. Report to Innovation Center for US Dairy, August 2013.

[5] EPA-Environmental Protection Act. An evaluation of a covered anaerobic lagoon for flushed dairy cattle manure stabilization and biogas production. Washington, D.C.: US Environmental Protection Agency, 2008.

[6] BioCycle. Anaerobic Digest. BioCycle 2014; 65(11): 16. Retrieved December $23^{\text {rd }}$, 2015, from: http://www.biocycle.net/2014/12/16/anaerobic-digest-45/

[7] Novak A. The Tectonic Shift of New Oil and Gas Technologies Has Only Just Begun, Forbes Magazine, Feb. $16,2012$.

[8] Coppedge B, Coppedge G, Evans D, Jensen J, Kanoa E, Scanlan K, Scanlan B, Weisberg P, Frear C. Renewable Natural Gas and Nutrient Recovery Feasibility for Deruyter Dairy. Olympia, WA: Washington State Department of Commerce, 2012.

[9] Liao W, Liu Y, Wen Z, Frear C, Chen Z. Kinetic Modeling of Enzymatic hydrolysis of cellulose in differently pretreated fibers from dairy manure. Biotechnol Bioeng 2008; 101(3): 441-51.

[10] MacConnell C, Frear C, Liao W. Pretreatment of AD-treated fibrous solids for value-added container media market, WSU Center for Sustaining Agriculture and Natural Resources, Pullman, WA, 2010.

[11] Frear C, Ma J. Wastewater Emission Parameters from Sequential Treatment of Dairy Manure. Report to SRA \& EPA. Pullman, WA, 2015.

[12] Elumalai S, Roa-Espinosa A, Markley JL, Runge TM. Combined sodium hydroxide and ammonium hydroxide pretreatment of post-biogas digestion dairy manure fiber for cost effective cellulosic bioethanol production. Sustainable Chem Processes 2014; 2:12.

[13] Angelidaki I, Ahring BK. Methods for increasing the biogas potential from the recalcitrant organic matter contained in manure. Water Sci Technol 2000; 41(3): 189-94.

[14] Hartmann H, Angelidki I, Ahring BK. Increase of anaerobic degradation of particulate organic matter in full scale biogas plants by mechanical maceration. Water Sci Technol 2000; 41(3):145-53. 
[15] Carrère H, Dumas C, Battimelli A, Batstone DJ, Delgenès JP, Steyer JP, Ferrer I. Pretreatment methods to improve sludge anaerobic degradability: a review. J Hazard Mater 2010; 183:1-15.

[16] Biswas R, Ahring BK, Uellendahl H. Improving biogas yields using an innovative concept for conversion of the fiber fraction of manure. Water Sci Technol 2012; 66(8):1751-58.

[17] Sheets JP, Yang L, Ge X, Wang Z, Li Y. Beyond land application: Emerging technologies for the treatment and reuse of anaerobically digested agricultural and food waste. Waste Manage 2015; 44: 94-115.

[18] Monlau F, Sambusiti C, Ficara E, Aboulkas A, Barakat A, Carrère H. New opportunities for agricultural digestate valorization: current situation and perspectives. Energy Environ. Sci. 2015; 8, 2600.

[19] Minnesota Project. Anaerobic Digesters: Farm Opportunities and Pathways. The Minnesota Project. St. Paul, MN, 2010.

[20] Alexander R. Digestate Utilization in the U.S. Biocycle. 2010; 53(1):56.

[21] Ma J, Kennedy N, Yorgey G, Frear C. Review of emerging nutrient recovery technologies for farm-based anaerobic digesters and other renewable energy systems. Report to the Innovation Center for US Dairy, 2013.

[22] DVO. DVO Incorporated, Chilton, WI, Personal communication, 2015.

[23] Informa Economics. National Market Value of Anaerobic Digester Products. Innovation Center for U.S. Dairy. Chicago, IL, 2013.

[24] Boote C. Eco-Composites, Perfect Cycle ${ }^{\circledR}$ Natural Bedding, personal communication, 2015.

[25] Perfect Cycle Natural Bedding (n.d.) Retrieved February $10^{\text {th }}$, 2016, from: http://www.perfectcyclenaturalbedding.com/

[26] Terre-Source, LLC. Study to Evaluate the Price and Markets for Residual Solids from a Dairy Cow Manure Anaerobic Digester-Final Report, King County Solid Waste, Seattle, WA, 2003.

[27] Martel S. Valorisation agronomique des digestats de méthanisation, Recherche documentaire, 2013. Retrieved December $20^{\text {th }}, 2014$, from: http://www.agrireseau.qc.ca/energie/documents/Synth\%C3\%A8se\%20recherche\%20documentaire_vfinale.pdf

[28] PacifiClean. Waste Management Service, Spokane, WA. Personal communication, 2015.

[29] Arancon N, Edwards C, Webster K, Buckerfield J. The Potential of Vermicomposts as Plant Growth Media for Greenhouse Crop Production. In: Edwards C, Arancon N, Sherman R, editors, Vermiculture Technology, Boca Raton, FL: CRC Press, 2010. 
[30] Edwards CA. The Use of Earthworms in the Breakdown and Management of Organic Wastes. In: Edwards C, editor, Earthworm Ecology: Boca Raton, FL, St. Lucie Press, 1998.

[31] Biernbaum JA. Root-zone management of greenhouse container-grown crops to control water and fertilizer use. HortTechnology 1992; 2(1): 127-32.

[32] Gouin F. Compost use in the horticultural industries. Green Industry Composting. BioCycle Special Report. The JG Press, Emmaus, PA, 1995.

[33] Bunt AC. Media and mixes for container-grown plants: a manual on the preparation and use of growing media for pot plants. 2nd ed. of Modern potting composts. Unwin Hyman Ltd., London, 1988.

[34] Fonteno WC. Growing media: types and physical/chemical properties. In D. W. Reed. (ed.) Water, media, and nutrition for greenhouse crops. Ball Publishing. Batavia, Ill, 1996.

[35] Chong C. Experiences with wastes and composts in nursery substrates. Hort Technol 2005; 15:739-47.

[36] Warren SL, Bilderback TE, Owen JS. Growing media for the nursery industry: Use of amendments in traditional bark-based media. Acta Hort 2009; 819:143-155.

[37] Raviv M. The future of composts as ingredients of growing media. Acta Hort 2011; 891:19-32.

[38] Schmilewski GK. Aspects of the raw material peat- resources and availability. Acta Hort. 1993; 150: 601-10.

[39] Schmilewski GK. Growing medium constituents used in the EU. Acta Hort. 2009; 819:33-45.

[40] Lu W, Sibley JL, Gilliam CH, Bannon JS, Zhang Y. Estimation of U.S. bark generation and implications for horticultural industries. J Environ Hort 2006; 24:29-34.

[41] Buamscha MG, Altland JE, Sullivan DM, Horneck DA, Cassidy J. Chemical and physical properties of Douglas fir bark relevant to the production of container plants. HortScience 2007; 42:1281-86.

[42] Bugbee GJ, Frink CR. Composted waste as a peat substitute in peat-lite media. HortScience 1989; 24:625-27.

[43] Kuo S, Ortiz-Escobar ME, Hue NV, Hummel RL. Composting and compost utilization for agronomic and container crops. Recent Res Devel Environ Biol 2004; 1:451-513 ISBN:81-7736-217-8, Research Signpost $37 / 661$ (2), Fort P.O., Trivandrum-695 023, Kerala, India.

[44] Boyer CR, Gilliam CH, Fain GB, Gallagher TV, Torbert HA, Sibley JL. Production of woody nursery crops in clean chip residual substrate. J Environ Hort 2009; 27:56-62.

[45] Jackson BE, Wright RD. Pine tree substrate: An alternative and renewable substrate for horticultural crop production. Acta Hort 2009; 819:265-72. 
[46] Bilderback TE, Riley ED, Jackson BE, Krause HT, Fonteno WC, Owen JS, Atland J, Fain GB. Strategies for developing sustainable substrates in nursery crop production. Acta Hort 2003; 1013:43-56.

[47] Carlile WR, Cattivello C, Zaccheo P. Organic growing media: constituents and properties. Vadose Zone J 2015; 14 (6), doi:10.2136/vzj2014.09.0125.

[48] Caron J, Heinse R, Charpentier S. Organic materials used in agriculture, horticulture, reconstructed soils, and filtering applications. Vadose Zone J 2015; 14 (6), doi:10.2136/vzj2015.04.0057.

[49] Raviv M, Chen Y, Geler Z, Medina S, Putievski E, Inbar Y. Slurry produced by methanogenic fermentation of cow manure as a growth medium for some horticultural crops. Acta Hort 1983; 150:563-73.

[50] MacConnell CB, Collins HP. Utilization of re-processed anaerobically digested fiber from dairy manure as a container media substrate. Acta Hort 2009; 819:279-86.

[51] Krucker M, Hummel RL, Cogger C. Chrysanthemum production in composted and noncomposted organic waste substrates fertilized with nitrogen at two rates using surface and subirrigation. HortScience 2010; 45:1695-701.

[52] Crippa L, Zaccheo P, Orfeo D. Utilization of the solid fraction of digestate from anaerobic digestion as container media substrate. Acta Hort 2013; 1013:367-73.

[53] Hummel RL, Cogger C, Bary A, Riley R. Marigold and pepper growth in container substrates made from biosolids composted with carbon-rich organic wastes. HortTechnology 2014; 24:325-33.

[54] Lamont, J.R. and Elliott, G.C. (2016) Anaerobically digested dairy fiber in soilless potting media for herbaceous perennials. American Journal of Plant Sciences, 7, 288-295.

[55] Lamont, J. R., \& Elliott, G. C. (2016). Anaerobically digested dairy fiber in soilless potting media for poinsettias. International Journal of Recycling of Organic Waste in Agriculture, 1-5. Int J Recycl Org Waste Agricult (2016) 5:173-177 DOI 10.1007/s40093-016-0130-X

[56] Yeager TH, Fare DC, Lea-Cox J, Ruter J, Bilderback TE, Gilliam CH, Niemiera AX, Warren SL, Whitwell TE, Wright RD, Tilt KM. Best management practices: Guide for producing container-grown plants. 2nd Ed. Southern Nurserymen’s Assoc., Marietta, GA, 2007.

[57] Nelson PV. Greenhouse operation and management. 7th ed. Pearson Prentice Hall, Upper Saddle River, NJ, 2012.

[58] Poole RT, Conover CA, Joiner JN. Soils and potting mixtures. In J.N. Joiner (ed.) Foliage Plant Production. Prentice-Hall, Englewood Cliffs, NJ, 1981. 
[59] Mattson, N. Substrate pH: Getting it right for your greenhouse crops. Cornell University Cooperative Extension. Retrieved July 12, 2015, from: http://www.greenhouse.cornell.edu/crops/factsheets/pHGreenhouseCrops.pdf.,

[60] Chen Y, Inbar Y, Raviv M, Dovrat A. The use of slurry produced by methanogenic fermentation of cow manure as a peat substitute in horticulture-physical and chemical characteristics. Acta Hort 1983; 150:553-61.

[61] Nordstedt RA, Sowerby ME. Final Report for Demonstration of On-site, In-vessel Dairy Manure Digestion, 2003. Retrieved July 12, 2015, from: http://dairy.ifas.ufl.edu/other/files/In-vesselDairyManureDigestion.pdf.

[62] Li Q, Chen J, Caldwell RD, Deng M. Cowpeat as a substitute for peat in container substrates for foliage plant production. Hort Technol 2009; 19:340-45.

[63] Schober AL, Wiese C, Denny GC, Stanley CD, Harbaugh BK, Chen J. Plant performance and nutrient losses during containerized bedding plant production using composted dairy manure solids as a peat substitute in substrate. HortScience 2010; 45:1516-21.

[64] Schober AL, Wiese C, Denny GC, Stanley CD, Harbaugh BK. Plant performance and nutrient losses during containerized landscape shrub production using composted dairy manure solids as a peat substitute in substrate. HortTechnology 2011; 21:240-45.

[65] Tangeman A, Sowerby M. Cowpeat can replace peat in potting mix. Progressive Dairyman, 2013. Retrieved July 11, 2015, from: http://www.progressivedairy.com/index.php?option=com_content\&id=3054:cowpeat-canreplace-peat-in-potting-mix \&Itemid=121.

[66] Matuana L, Gould MC. Promoting the use of digestate from anaerobic digesters in composite materials, Final report, Community Energy Project Grant No. PLA-06-42, 2006.

[67] Winandy JE, Cai Z. Potential of using anaerobically digested bovine biofuels as a fiber source for wood composites. BioResources 2008; 3(4): 1244-55.

[68] Spelter H, Winandy JE, Zauche T. Anaerobically digested bovine biofiber as source of fiber for particleboard manufacturing. BioResources 2008; 3(4): 1256-66.

[69] Dvorak S, Hunt JF. Composite materials from anaerobic digested fibrous materials, US Patent 8414808B2, 2013.

[70] Ferraz GP, Frear C, Pelaez-Samaniego MR, Englund K, Garcia-Perez M. Hot Water Extraction of Anaerobic Digested Dairy Fiber for Wood Plastic Composite Manufacturing, BioResources 2016; 11(4): 8139-8154. 
[71] American National Standards Institute, ANSI-A208.1-1999 Particleboard, Composite Panels Association, Gaithersburg, MD.

[72] American National Standards Institute, ANSI-A208.2-2002 Medium Density Fiberboard (MDF) For Interior Applications, Composite Panels Association, Gaithersburg, MD.

[73] Pelaez-Samaniego MR, Yadama V, Lowell E, Espinoza-Herrera R. A review of wood thermal pretreatments to improve wood composite properties, Wood Sci Technol 2013; 47:1285-319.

[74] Pelaez-Samaniego MR, Yadama V, Lowell E, Amidon T, Chaffee TL. Hot water extracted wood fiber for production of wood plastic composites (WPCs), Holzforschung 2012. 67(2): 193-200.

[75] Ng B-C, Bradfield C, Pritish R, Murray M. Potential fiberboard material from cow manure and disposable water bottle, Proceedings of the TMS $2012141^{\text {st }}$ Annual Meeting and Exhibition, Materials Processing and Interfaces, The Minerals, Metals \& Materials Society (TMS), 2012; 1: 118-123.

[76] Rowell RM, O’Neill E, Krzysik A, Bossmasn D, Galloway DF, Hemenover M. Incorporation of Animal Manures as Reinforcing Fillers in High-Density Polyethylene and High-Density Polypropylene Composites, 9th International Conference on Wood \& Biofiber Plastic Composites. May 21-23, 2007. Monona Terrace Community \& Convention Center Madison, WI, USA, Proceedings No. 7224.

[77] Rowell RM, O’Neill E, Krzysik A, Bossmasn D, Galloway DF, Hemenover M. Industrial application of animal manure filled thermoplastics, Mol Cryst Liq Cryst 2008; 484: 250/[616]-256/[622].

[78] Teater C, Yue ZB, MacLellan J, Liu Y, Liao W. Assessing solid digestate from anaerobic digestion as feedstock for ethanol production. Bioresource Technol 2011; 102(2):1856-862.

[79] Yue Z, Teater C, Liu Y, MacLellan J, Liao W. A sustainable pathway of cellulosic ethanol production integrating anaerobic digestion with biorefining. Biotechnol Bioeng 2010; 105(6):1031-39.

[80] Yue Z, Teater C, MacLellan J, Liu Y, Liao W. Development of a new bioethanol feedstock- Anaerobically digested fiber from confined dairy operations using different digestion configurations. Biomass Bioener 2011; 35: 1946-53.

[81] Yue Z, Chen R, Yang F, MacLellan J, Marsh T, Liu Y, Liao W. Effects of dairy manure and corn stover codigestion on anaerobic microbes and corresponding digestion performance. Bioresource Technol 2013; 128:6571.

[82] Liao W, Wen Z, Hurley S, Liu Y, Liu C, Chen S. Effects of hemicellulose and lignin on enzymatic hydrolysis of cellulose from dairy manure. Appl Biochem Biotechnol 2005; 121-124: 1017-30. 
[83] Liao W, Liu Y, Liu C, Wen Z, Chen S. Acid hydrolysis of fibers from dairy manure. Bioresource Technol 2006; 97: 1687-95.

[84] Wen Z, Liao W, Chen S. Hydrolysis of animal manure lignocellulosics for reducing sugar production. Bioresource Technol 2004; 91: 31-9.

[85] Zhong Y, Ruan ZH, Zhong YK, Archer S, Liu Y, Liao W. A self-sustaining advanced lignocellulosic biofuel production by integration of anaerobic digestion and aerobic fungal fermentation. Bioresource Technol 2015; 179:173-9.

[86] Hussain J, Ruan ZH, Nascimento IA, Liu Y, Liao W. Lipid profiling and corresponding biodiesel quality of Mortierella isabellina using different drying and extraction methods. Bioresource Technol 2004; 169:768-72.

[87] Liao W, Liu Y, Hodge D. Integrated farm-based biorefinery. In: Qureshi N, Hodge D, Vertes A, editors. Biorefineries: Integrated Biochemical Processes for Liquid Biofuels. Amsterdam, Netherlands: Elsevier. 2014.

[88] Wang L, Li Y, Chen P, Min M, Chen Y, Zhu J, et al. Anaerobic digested dairy manure as a nutrient supplement for cultivation of oil-rich green microalgae Chlorella sp. Bioresour. Technol. 2010; 101: 2623-2628.

[89] Streubel JD. Biochar: its characterization and utility for recovering phosphorus from anaerobic digested dairy effluent, Ph.D. Dissertation, Washington State University, Pullman, WA, 2011.

[90] Streubel JD, Collins HP, Garcia-Perez M, Tarara J, Granatstein D, Kruger CE. Influence of Contrasting Biochar Types on Five Soils at Increasing Rates of Application. Soil Sci Soc Am J 2011; 75:1402-13.

[91] Streubel JD, Collins HP, Tarara JM, Cochran RL. Biochar produced from anaerobically digested fiber reduces phosphorus in dairy lagoons. J Environ Qual 2012; 41, doi:10.2134/jeq2011.0131.

[92] Enders A, Hanley K, Whitman T, Joseph S, Lehmann J. Characterization of biochars to evaluate recalcitrance and agronomic performance. Bioresource Technol 2012; 114: 644-53.

[93] Rajkovich S, Enders A, Hanley K, Hyland C, Zimmerman AR, Lehmann J. Corn growth and nitrogen nutrition after additions of biochars with varying properties to a temperate soil. Biol Fertil Soils 2012; 48:271-84.

[94] Graydon JW, Kirk DW, White AJ. Production of biochar absorbent from anaerobic digestate, International Application Patent WO2012094736A1, 2012.

[95] Inyang M, Gao B, Yao Y, Xue Y, Zimmerman AR, Pullammanappallil P, Cao X. Removal of heavy metals from aqueous solution by biochars derived from anaerobically digested biomass. Bioresource Technol 2012; 110: 50-6. 
[96] Kirk DW, Graydon JW, White AJ. Production of biochar absorbent from anaerobic digestate, US Patent 2013/0295634 A1, 2013.

[97] McBeath AV, Smernik RJ, Krull ES, Lehmann J. The influence of feedstock and production temperature on biochar carbon chemistry: A solid-state 13C NMR study. Biomass Bioener 2014; 60: 121-9.

[98] Miller NF. The use of dung fuel: An ethnographic example and an archeological application, Paléorient 1984; 10(2): 71-9.

[99] Barnes DF, Openshaw K, Smith KR, van der Plas R. What makes people cook with improved biomass stoves? A comparative international review of stove programs, World Bank Technical Paper Number 242. Energy Series, Washington DC, 1994.

[100] Mlekuz D. The materiality of dung: the manipulation of dung in Neolithic Mediterranean caves, Documenta Praehistorica 2009; XXXVI: 219-25.

[101] Davis EG, Feld IL, Brown JH. Combustion Disposal of Manure Wastes and Utilization of the Residue, USDI Bureau of Mines, Tech Proq Rpt 1972; 46, 13p.

[102] Whetstone GA, Parker HW, Wells DM. Study of current and proposed practices in animal waste management, Environmental Protection Agency, Office of Air and Water Programs, EPA 430/9-74-003, 1974.

[103] Annamalai K, Thien B, Sweeten J. Co-firing of coal and cattle feedlot biomass (FB) fuels. Part II. Performance results from $30 \mathrm{kWt}(100,000)$ BTU/h laboratory scale boiler burner. Fuel 2003; 82: 1183-93. [104] Annamalai K, Sweeten JM, Auvermann BW, Mukhtar S, Caperada S, Engler CR, Harman W, Reddy JN, Deotte R. Renewable energy and environmental sustainability using biomass from dairy and beef animal production, Final Report. Vol. 1: Thermo-chemical conversion and direct combustion methods, DE-FG3605GO85003, 2012.

[105] Kennedy P. Dairy manure waste fiber to energy process, US Patent 2014/0250776 A1, 2014.

[106] Sweeten JM, Annamalai K, Thien B, McDonald LA. Co-firing of coal and cattle feedlot biomass (FB) fuels. Part I. Feedlot biomass (cattle manure) fuel quality and characteristics. Fuel 2003; 82: 1167-82.

[107] Edström M, Schüßler I, Luostarinen S. Baltic Manure WP6 Energy potentials, Combustion of manure: Manure as fuel in a heating plant, 2011 (Retrieved December $11^{\text {th }}, 2014$ : http://balticmanure.eu/download/Reports/baltic_manure_combustion_final_2_2011_total.pdf).

[108] Sweeten JM, Korenberg J, LePori WA, Annamalai K, Parnell CB. Combustion of cattle feedlot manure for energy production. Energ Agriculture 1986; 5(1): 55-72. 
[109] Annamalai K, Ibrahim MY, Sweeten JM. Experimental Studies on Combustion of Cattle Manure in a Fluidized Bed Combustor. J Energy Resour Technol 1987; 109(2): 49-57, doi:10.1115/1.3231324.

[110] Annamalai K, Frazzitta S, Sweeten JM. Performance of a burner with coal and coal:manure blends. CONF960154-ISBN 0-9648731-8-4; TRN: IM9642\%\%409, Conference: Energy Week'96: American Society of Mechanical Engineers and American Petroleum Institute energy week conference and exhibition, Houston, TX (United States), 21 Jan-2 Feb 1996; ISBN 0-9648731-8-4

[111] Annamalai K, Sweeten J, Freeman M, Mathur M, O’Dowd W, Walbert G, Jones S. Co-firing of coal and cattle feedlot biomass (FB) Fuels, Part III: fouling results from a 500,000 BTU/h pilot plant scale boiler burner. Fuel 2003; 82: 1195-200.

[112] Frazzitta S, Annamalai K, Sweeten J. Performance of a Burner with Coal and Coal-Bio-Solid Fuel Blends. J Propul Power 1999; 15(2): 181-6.

[113] Sweeten JM, Annamalai K, Heflin K, Freeman M. ASAE Annual International Meeting, Chicago, IL, July 28$31,2002$.

[114] Carlin N, Annamalai K, Sweeten J, Mukhtar S. Thermo-chemical conversion analysis on dairy manure-based biomass through direct combustion. Int J Green Ener 2007; 4(2): 133-59.

[115] Carlin NT. Optimum usage and economic feasibility of animal manure based biomass in combustion systems, Ph.D. Dissertation, Texas A\&M University, 2009.

[116] Carlin NT, Annamalai K, Harman WL, Sweeten JM. The economics of reburning with cattle manure-based biomass in existing coal-fired power plants for NOx and CO2 emissions control. Biomass Bioener 2009; 33 : $1139-57$

[117] Lawrence B, Annamalai K, Sweeten JM, Heflin K. Cofiring coal and dairy biomass in a 29 kWt furnace. Appl Energy 2009; 86: 2359-72.

[118] Wu H, Hanna MA, Jones DD. Thermogravimetric characterization of dairy manure as pyrolysis and combustion feedstocks. Waste Manage Res 2012; 30(10): 1066-71.

[119] Cantrell KB, Martin JH, Ro KS. Application of Thermogravimetric Analysis for the Proximate Analysis of Livestock Wastes. J ASTM Intl 2011; 7(3). doi:10.1520/JAI102583.

[120] Mukhtar S, Capareda S. Manure to Energy: Understanding Processes Principles and Jargon, 2011. Retrieved December 11th, 2014, from: http://tammi.tamu.edu/ManurtoEnrgyE428.pdf. 
[121] Massie JR Jr. Continuous Refuse Retort - A Feasibility Investigation, MS Thesis. MS in ChE, Texas Tech University, 54 p, 1972.

[122] Retan GA. Charcoal as a means of solving some nursery problems. Forestry Quarterly 1915; 13: 25-30.

[123] Morley J. Compost and charcoal, The National Greenkeeper 1929; 3(9): 8-26.

[124] Verona O, Ciriotti P. Azione del carbone sulla vegetazione. V. Ii carbone animiale. Bol. Del R. Instit. Sup. Agr Pisa 1935; 14: 401-20.

[125] Verona 0. Influenza esercitata sulla vegetazione dai carboni attivati con particolare riguardo al loro potere disintossicante. Bol della Fac Agr 1938; 16: 383-5.

[126] Tryon EH. Effect of charcoal on certain physical, chemical, and biological properties of forest soils. Ecol Monogr 1948; 18: 81-115.

[127] Spokas KA, Cantrell KB, Novak JM, Archer DW, Ippolito JA, Collins HP, Boateng AA, Lima IM, Lamb MC, McAloon AJ, Lentz RD, Nichols KA. Biochar: A synthesis of its agronomic impact beyond carbon sequestration. J Environ Qual 2012; 41: 973-89.

[128] Shinogi Y, Kanri Y. Pyrolysis of plant, animal and human waste: physical and chemical characterization of the pyrolytic products. Bioresource Technol 2003; 90: 241-7

[129] Singh B, Singh BP, Cowie AL. Characterisation and evaluation of biochars for their application as a soil amendment. Aust J Soil Res 2010; 48:516-25.

[130] Cantrell KB, Hunt PG, Uchimiya M, Novak JM, Ro KS. Impact of pyrolysis temperature and manure source on physicochemical characteristics of biochar. Bioresource Technol 2012; 107:419-28.

[131] Cao X, Harris W. Properties of dairy-manure-derived biochar pertinent to its potential use in remediation, Bioresource Technol 2010; 101:5222-28.

[132] Cao X, Ma L, Gao B, Harris W. Dairy-Manure Derived Biochar Effectively Sorbs Lead and Atrazine. Environ Sci Technol 2009; 43:3285-91.

[133] Xu X, Cao X, Zhao L, Wang H, Yu H, Gao B. Removal of Cu, Zn, and Cd from aqueous solutions by the dairy manure-derived biochar. Environ Sci Pollut Res; 2013; 20:358-68.

[134] Bridgeman TG, Jones JM, Williams A, Waldron DJ. An investigation of the grind ability of two torrefied energy crops. Fuel 2010; 89:3911-8.

[135] Repellin V, Govin A, Rolland M, Guyonnet R. Energy requirement for fine grinding of torrefied wood. Biomass Bioenerg 2010; 34:923-30. 
[136] Xu X, Cao X, Zhao L, Zhoua H, Luo Q. Interaction of organic and inorganic fractions of biochar with $\mathrm{Pb}(\mathrm{II})$ ion: further elucidation of mechanisms for $\mathrm{Pb}$ (II) removal by biochar. RSC Adv 2014; 4:44930-7.

[137] Liang Y, Cao X, Zhao L, Xu X, Harris W. Phosphorus Release from Dairy Manure, the Manure-Derived Biochar, and Their Amended Soil: Effects of Phosphorus Nature and Soil Property. J Environ Qual 2014; 43:1504-09.

[138] Uchimiya M, Cantrell KB, Hunt PG, Novak JM, Chang S. Retention of heavy metals in a typic kandiudult amended with different manure-based biochars. J Environ Qual 2012; 41:1138-49.

[139] Kołodynska D, Wnetrzak R, Leahy JJ, Hayes MHB, Kwapinski W, Hubicki Z. Kinetic and adsorptive characterization of biochar in metal ions removal. Chem Eng J 2012; 197: 295-305

[140] Cantrell KB, Martin JH. Stochastic state-space temperature regulation of biochar production. Part II: Application to manure processing via pyrolysis. J Sci Food Agric 2012; 92:490-5.

[141] Wang T, Arbestain MC, Hedley M, Bishop P. Chemical and bioassay characterisation of nitrogen availability in biochar produced from dairy manure and biosolids, Org Geochem 2012; 51:45-54.

[142] Wang T, Arbestain MC, Hedley M, Bishop P. Predicting phosphorus bioavailability from high-ash biochars. Plant Soil 2012; 357:173-87.

[143] Domene X, Enders A, Hanley K, Lehmann J. Ecotoxicological characterization of biochars: Role of feedstock and pyrolysis temperature. Sci Total Environ 2015; 512-513:552-61.

[144] Uzoma KC, Inoue M, Andry H, Fujimaki H, Zahoor A, Nishihara E. Effect of cow manure biochar on maize productivity under sandy soil condition. Soil Use Manage 2011; 27:205-12

[145] Wisconsin Department of Agriculture, Trade and Consumer Protection. Market Feasibility for Products Developed at the Cashton Greens Energy Park, Cashton Area Development Corporation, 2006. Retrieved Jan. $23^{\text {rd }}, 2015$, from: http://datcp.wi.gov/uploads/Business/pdf/20076Cashton.pdf

[146] Xu Y, Chen B. Investigation of thermodynamic parameters in the pyrolysis conversion of biomass and manure to biochars using thermogravimetric analysis, Bioresource Technol 2013; 146:485-93.

[147] Cao H, Xin Y, Wang D, Yuan Q. Pyrothermolysis characteristics of cattle manures using a discrete distributed activation energy model. Bioresource Technol 2014; 172:219-25.

[148] Gomez X, Diaz MC, Cooper M, Blanco D, Moran A, Snape CE. Study of biological stabilization processes of cattle and poultry manure by thermogravimetric analysis and 13C NMR. Chemosphere 2007; 68: 1889-97. 
[149] Qian Q, Machida M, Tatsumoto H. Preparation of activated carbons from cattle-manure compost by zinc chloride activation. Bioresource Technol 2007; 9:353-60.

[150] Qian Q, Machida M, Tatsumoto H. Textural and surface chemical characteristics of activated carbons prepared from cattle manure compost. Waste Manage 2008; 28: 1064-71.

[151] Garner W, Smith IC. The Disposal of Cattle Feedlot Wastes by Pyrolysis Environ. Protection Tech. Project EPA-R2-73-096, Contract No. 14-12-850, 99 p., 1973.

[152] White RK, Taiganides EP. Pyrolysis of livestock wastes. Livestock waste management and pollution abatement, Proceedings of the International Symposium on Livestock Wastes, April 19-22, Ohio State University, OH, 1971.

[153] Beck SR, Halligan JE, Lin CS, Bartsch RA, Huffman WJ, Landeene BC, Ravi R, Hillman PE. Partial oxidation: pyrolysis of cattle feedlot manure in the SGFM reactor. Final report, Contract E(29-2)-3779, 1977. (http://www.osti.gov/scitech/servlets/purl/6023064)

[154] Beck SR, Huffman WJ, Landeene BL, Halligan JE. Pilot plant results for partial oxidation of cattle feedlot manure. Ind Eng Chem Process Des Dev 1979; 18(2):328-32.

[155] Engler CR, Walawender WP, Fan LT. Synthesis gas from feedlot manure. Conceptual design study and economic analysis. Environ Sci Technol 1975; 9(13):1152-7.

[156] Fan LT, Walawender WP. Pyrolytic conversion of carbonaceous solids to fuel gas in quartz sand fluidized beds, United States Patent US4448589 A, 1984.

[157] Gordillo G, Annamalai K. Gasification of Coal and Dairy Manure With Air-Steam as Oxidizing Agent, ASME/JSME 2007 Thermal Engineering Heat Transfer Summer Conference, 1: 555-563, Vancouver, BC, Canada, July 8-12, 2007.

[158] Gordillo G, Annamalai K, Carlin N. Adiabatic fixed-bed gasification of coal, dairy biomass, and feedlot biomass using an air-steam mixture as an oxidizing agent. Ren Energy 2009; 34: 2789-97.

[159] Gordillo G, Annamalai K. Adiabatic fixed bed gasification of dairy biomass with air and steam. Fuel 2010; 89: 384-91.

[160] Gordillo G, Annamalai K. Dairy Biomass-Wyoming Coal Blends Fixed Gasification Using Air-Steam for Partial Oxidation. J Combustion, 2012; Article ID 495894, 7 p.

[161] Halligan JE, Herzog KL, Parker HW. Synthesis Gas from Bovine Wastes. Ind Eng Chem Process Des Develop 1975; 14(1):64-9. 
[162] Huffman WJ, Peterson RL, Halligan JE. Ammonia Synthesis Gas Generation from Cattle Feedlot Manure, Centennial ACS Meeting Di. Ferti. Soil Chem, April 6-7, 1976.

[163] Huffman WJ, Beck SR, Landeene BL, Halligan JE. A review of heat/mass balances and product data for partial oxidation of cattle feedlot manure. AIChE 84th National Meeting Atlanta, GA, Feb. 26-Mar 1, 1978. doi:10.2172/6498307, Retrieved February 3rd, 2015, from: http://www.osti.gov/scitech/servlets/purl/6498307

[164] Huffman WJ, Halligan HE, Peterson RL. Conversion of cattle feedlot manure to ethylene and ammonia synthesis gas, Robert S. Kerr Environmental Research Laboratory, Grant No. S-802934, ADA, OK, 1978.

[165] Kunzru D, Ali M. Pyrolysis of bovine waste. Fuel 1981; 60(5): 447-51.

[166] Madden D. Feedlot Energy System and the Value of Manure, Gasification of feedlot manure for energy in feed manufacture, December 2011, Nuffield Australia Project No 1015.

[167] Matsumura Y, Minowa T, Potic B, Kersten SRA, Prins W, van Swaaij WPM, van de Beld B, Elliott DC, Neuenschwander GG, Kruse A, Antal Jr. MJ. Biomass gasification in near- and super-critical water: Status and prospects. Biomass Bioener 2005; 29:269-92.

[168] Raman KP, Walawender WP, Fan LT. Gasification of feedlot manure in a fluidized bed reactor. The effect of temperature. Ind Eng Chem Process Des Dev 1980; 19:623-9.

[169] Raman KP, Walawender WP, Fan LT. Gasification of feedlot manure in a fluidized bed. The effects of superficial gas velocity and feed size fraction, 233-244, January 1980. Retrieved February 2016, from: https://web.anl.gov/PCS/acsfuel/preprint\%20archive/Files/25_4_SAN\%20FRANCISCO_08-80_0233.pdf

[170] Raman P, Walawender WP, Fan LT, Chang CC. Mathematical Model for the Fluid-Bed Gasification of Biomass Materials. Application to Feedlot Manure. Ind Eng Chem Process Des Dev 1981; 20: 686-92.

[171] Pian CCP, Yoshikawa K. Performance of biomass-fueled high-temperature air blown gasification systems. In: Proceedings of the Third International Symposium on High Temperature Air Combustion and Gasification. Yokohama, Japan: Tokyo Institute of Technology. p. A6-1-12, 2000.

[172] Pian CCP, Yoshikawa K. Biomass-fueled, high-temperature, air-blown gasification systems, 2000. AIAA2000-2944, 793-803.

[173] Priyadarsan S, Annamalai K, Sweeten JM, Mukhtar S, Holtzapple MT. Fixed-bed gasification of feedlot manure and poultry litter biomass. American Society of Agricultural Engineers, St Joseph, USA, Transactions of the ASABE 2004; 47(5):1689-96. 
[174] Priyadarsan S, Annamalai K, Sweeten JM, Holtzapple MT, Mukhtar S. Co-gasification of blended coal with feedlot and chicken litter biomass. Proceedings of the Combustion Institute 2005; 30(2): 2973-80.

[175] Thanapal SS, Annamalai K, Sweeten JM, Gordillo G. Fixed bed gasification of dairy biomass with enriched air mixture, Appl Energ 2012; 97:525-31.

[176] Wu H, Hanna MA, Jones DD. Fluidized-bed gasification of dairy manure by Box-Behnken design. Waste Manage Res 2012; 30(5):506-511.

[177] Wu H. Biomass gasification: an alternative solution to animal waste management, Ph.D. Dissertation, Lincoln, Nebraska, 2013.

[178] Wu H, Hanna MA, Jones DD. Life cycle assessment of greenhouse gas emissions of feedlot manure management practices: Land application versus gasification, Biomass Bioener 2013; 54:260-6.

[179] Young L, Pian CCP. High-temperature, air-blown gasification of dairy-farm wastes for energy production. Energy 2003; 28: 655-72.

[180] Midwest Energy Research Center, n.d. Turning manure into gold: Converting agricultural waste to energy, Retrieved April 21st, 2015, from: http://www.manuremanagement.cornell.edu/Pages/General_Docs/Reports/Turning_Manure_to_Gold.pdf.

[181] Elliot DC. Hydrothermal processing, In: Thermochemical processing of biomass: Conversion into fuels, chemicals, and power, First Edition, Edited by C. Brown, John Wiley and Sons, 2011.

[182] Berl E. Production of oil from plant material. Science 1944; 99(2573):309-12.

[183] Fu YC, Illig EG, Metlin SJ. Conversion of manure to oil by catalytic hydrotreating. Env Sci Technol 1974; 8(8): 737-40.

[184] Yin S, Dolan R, Harris M, Tan Z. Subcritical hydrothermal liquefaction of cattle manure to bio-oil: Effects of conversion parameters on bio-oil yield and characterization of bio-oil. Bioresource Technol 2010; 101(10): $3657-64$.

[185] Theegala CS, Midgett JS. Hydrothermal liquefaction of separated dairy manure for production of bio-oils with simultaneous waste treatment. Bioresource Technol 2012; 107:456-63.

[186] Elliott DC, Neuenschwander GG, Hart TR, Butner RS, Zacher AH, Engelhard MH, Young JS, McCready DE. Chemical Processing in High-Pressure Aqueous Environments. 7. Process Development for Catalytic Gasification of Wet Biomass Feedstocks. Ind Eng Chem Res 2004; 43(9):1999-2004. 
[187] Ro KS, Cantrell K, Elliott D, Hunt PG. Catalytic Wet Gasification of Municipal and Animal Wastes. Ind. Eng. Chem. Res. 2007; 46(26):8839-45.

[188] Yakaboylu O, Harinck J, Smit KGJ, de Jong W. Supercritical water gasification of manure: A thermodynamic equilibrium modeling approach. Biomass Bioenerg 2013; 59: 253-63.

[189] Kiang KD, Feldmann HF, Yavorsky PM. Hydrogasification of cattle manure to pipeline gas. Presented at the 165th National Meeting of the American Chemical Society, Dallas, Texas. pp. 15-23, 1973.

[190] Kreis RD. Recovery of By-Products from Animal Wastes. A Literature Review. Environmental Protection Agency, Document EPA-600/2-79-142, 51 p., 1979.

[191] Dai L, Tan F, Wu B, He M, Wang W, Tang X, Hu Q, Zhang M. Immobilization of phosphorus in cow manure during hydrothermal carbonization. J Environ Management 2015; 157: 49-53.

[192] Cantrell K, Ro K, Mahajan D, Anjom M, Hunt PG. Role of Thermochemical Conversion in Livestock Wasteto-Energy Treatments: Obstacles and Opportunities. Ind Eng Chem Res 2007; 46:8918-27.

[193] Pelaez-Samaniego MR, Yadama V, Garcia-Perez M, Lowell E, McDonald M. Effect of torrefaction temperature on the formation of lignin liquid intermediates. J Anal Appl Pyrolysis 2014; 109:222-33.

[194] Pelaez-Samaniego MR, Yadama V, Garcia-Perez M, Lowell E. Abundance and Characteristics of Lignin Liquid Intermediates in Wood (Pinus ponderosa Dougl. ex Laws.) during Hot Water Extraction. Biomass Bioenerg 2015; 81: 127-8.

[195] Pellet Fuel Institute. Pellet Fuel Institute Standard Specification for Residential/Commercial Densified Fuel. Arlington, VA, 2008.

[196] Wang S, Wang H, Yin Q, Zhu L, Yin S. Methanation of bio-syngas over a biochar supported catalyst. New J Chem 2014; 38: 4471-77.

[197] Ryi S-K, Lee S-W, Hwang K-R, Park J-S. Production of synthetic natural gas by means of a catalytic nickel membrane. Fuel 2012; 94:64-69.

[198] Liu Z, Chu B, Zhai X, Jin Y, Cheng Y. Total methanation of syngas to synthetic natural gas over Ni catalyst in a micro-channel reactor. Fuel 2012; 95:599-605.

[199] Kopyscinski J, Schildhauer TJ, Biollaz SMA. Production of synthetic natural gas (SNG) from coal and dry biomass - A technology review from 1950 to 2009. Fuel 2012; 89:1763-83.

[200] Josse JC, Benedek A. Syngas biomethanation process and anaerobic digestion system, US Patent 2013/0203144 A1, 2013. 
[201] Basu P. Biomass Gasification and Pyrolysis, Practical Design and Theory, Elsevier, Oxford, 2010. 
Table 1. Some characteristics of AD dairy fiber (dry basis)

\begin{tabular}{|c|c|c|c|}
\hline \multirow[t]{2}{*}{ Parameter } & \multirow[t]{2}{*}{ Unit } & \multicolumn{2}{|l|}{ Value } \\
\hline & & $\operatorname{Ref}[10]$ & $\operatorname{Ref}[12]$ \\
\hline TS (total solids) & $\%$ & 24.43 & - \\
\hline VS (volatile solids) & $\% \mathrm{TS}$ & 92.00 & - \\
\hline Density & $\mathrm{kg} / \mathrm{m}^{3}$ & 400.56 & - \\
\hline $\mathrm{C}$ & $\%$ & - & $39.1 \pm 0.4$ \\
\hline $\mathrm{N}$ & $\%$ & 1.42 & $3.3 \pm 0.2$ \\
\hline $\mathrm{P}$ & $\%$ & 0.28 & $1.1 \pm 0.0$ \\
\hline K & $\%$ & 0.68 & $1.4 \pm 0.0$ \\
\hline $\mathrm{Ca}$ & $\%$ & 1.44 & $4.8 \pm 0.6$ \\
\hline $\mathrm{Mg}$ & $\%$ & 0.28 & $0.8 \pm 0.1$ \\
\hline $\mathrm{Na}$ & $\%$ & 0.27 & - \\
\hline S & $\%$ & 0.50 & $1.0 \pm 0.0$ \\
\hline $\mathrm{Cu} ; \mathrm{Zn} ; \mathrm{Mn} ; \mathrm{Fe} ; \mathrm{B}$ & ppm & $99.33 ; 98.67 ; 929.33 ; 27.83$ & - \\
\hline $\mathrm{C} / \mathrm{N}^{\mathrm{a}}$ & - & 36.70 & - \\
\hline Ash & $\%$ & - & $13.7 \pm 0.1$ \\
\hline Extractives & $\%$ & - & $11.7 \pm 0.1$ \\
\hline Cellulose (Glucose) & & $35.7 \pm 1.4$ & $23.6 \pm 0.3$ \\
\hline $\begin{array}{l}\text { Hemicelluloses (Galactose, Arabinose, } \\
\text { Xylose, Mannose) }\end{array}$ & $\%$ & $9.2 \pm 1.0$ & $17.5 \pm 0.5$ \\
\hline Acid soluble lignin & $\%$ & - & $1.8 \pm 0.0$ \\
\hline Acid insoluble lignin & $\%$ & $27.7 \pm 0.7$ & $27.6 \pm 0.1$ \\
\hline
\end{tabular}


Table 2. Typical yields of products of the pyrolysis of steer manure (dry weight basis) [151].

\begin{tabular}{|l|l|}
\hline Char & $35.7 \%$ \\
\hline Ash & $9.2 \%$ \\
\hline Carbonaceous residue & $26.5 \%$ (by difference) \\
\hline Low-boiling organics & $7.3 \%$ \\
\hline Tarry volatile organics & $14.2 \%$ \\
\hline Reaction water & $16.7 \%$ \\
\hline Noncondensable gases & $26.1 \%$ (by difference) \\
\hline
\end{tabular}

